\title{
ASSESSING EUROPEAN FIRMS' EXPORTS AND PRODUCTIVITY DISTRIBUTIONS: THE COMPNET TRADE MODULE
}

\section{Antoine Berthou, Emmanuel Dhyne, Matteo} Bugamelli, ANA-MaRia CAZACU, CALIN-VLAD DEMian, Peter Harasztosi, Tibor Lalinsky, JaAnikA MERIKÜLL, FiLIPPO OROPALlo AND ANA CRISTinA SOARES

\section{WORKING


(C) Národná banka Slovenska

Imricha Karvaša 1

81325 Bratislava

www.nbs.sk

research@nbs.sk

December 2016

ISSN $1337-5830$

The views and results presented in this paper are those of the authors and do not necessarily represent the official opinions of the National Bank of Slovakia.

All rights reserved. 


\title{
Assessing European firms' exports and productivity distributions: the CompNet trade module ${ }^{1}$
}

\author{
Working paper NBS \\ Antoine Berthou, Emmanuel Dhyne, Matteo Bugamelli, Ana-Maria Cazacu, Calin-Vlad \\ Demian, Peter Harasztosi, Tibor Lalinsky, Jaanika Meriküll, Filippo Oropallo \\ and Ana Cristina Soares ${ }^{2}$
}

\begin{abstract}
This paper provides a new cross-country evaluation of competitiveness, focusing on the linkages between productivity and export performance among European economies. We use the information compiled in the Trade module of CompNet to establish new stylized facts regarding the joint distributions of the firm-level exports performance and productivity in a panel of 15 countries, 23 manufacturing sectors during the 2000's. We confirm that exporters are more productive than non-exporters. However, this productivity premium is rising with the export experience of firms, with permanent exporters being much more productive than starters. At the intensive margin, we show that both the level and the growth of firm-level exports rise with firm productivity, and that the bulk of aggregate exports in each country are made by a small number of highly productive firms. Finally, we show that during the crisis, the growth of exports by high productive firms sustained the current account adjustment of European "stressed" economies. This last result confirms that the shape of the productivity distribution within each country can have important consequences from the point of view of the dynamics of aggregate trade patterns.
\end{abstract}

JEL classification: F10, F14

Keywords: Firm-level exports, productivity, firm heterogeneity.

Downloadable at http://www.nbs.sk/en/publications-issued-by-the-nbs/working-papers

\footnotetext{
${ }^{1}$ The authors thank the CompNet team at the ECB for its coordination support making the whole exercise possible, as well as the National Central Banks that participated to this program and ran the CompNet's Trade module on their firm-level datasets. No firm-level information or confidential data was disclosed outside of the Central Banks or National Statistical Institutes. Results presented in this paper respect the confidentiality requirements legally imposed. This paper does not reflect the view of the National Central Banks of the ESCB or the European Central Bank.

${ }^{2}$ Antoine Berthou (Banque de France), Emmanuel Dhyne (National Bank of Belgium), Matteo Bugamelli (Banca d'Italia), AnaMaria Cazacu (Banca Nationala a României), Calin-Vlad Demian (European Central Bank), Peter Harasztosi (Magyar Nemzeti Bank), Tibor Lalinsky (Národná banka Slovenska), Jaanika Meriküll (Eesti Pank), Filippo Oropallo (ISTAT), Ana Cristina Soares (Banco de Portugal).
} 


\section{NON-TECHNICAL SUMMARY}

Improving external cost and price competitiveness may be achieved either through a more rapid productivity growth, or through wage moderation, i.e. internal devaluation. However, fostering aggregate productivity growth is generally expected to be more growth-friendly, as an internal devaluation is equivalent to a loss of terms of trade and has a negative influence on aggregate welfare. Understanding how aggregate exports can be sustained by a more dynamic productivity growth is therefore essential for the implementation of procompetitiveness policies, especially in countries facing rapid current account adjustment.

So far, the evaluation of European countries' competitiveness has mainly relied on Unit Labor Costs (ULCs) indicators, which combine aggregate information about real productivity and wage dynamics. Empirical evidence shows that in Europe during the 2000's, aggregate export performance was imperfectly predicted by the growth of unit labor costs. This apparent puzzle may have different origins, ranging from unobserved macroeconomic shocks (such as the role of capital flows) to the unobserved heterogeneity at the micro level, which we explore in details. Exporters may have indeed different productivity and wage dynamics than non-exporters, leading to an aggregation bias. Also, unobserved microeconomic heterogeneity within sectors, related to the distribution of productivities across firms, and to the concentration of activity among a small subset of firms, may affect the reaction of aggregate exports to external shocks such as exchange rates movements or foreign demand variations.

The objective of this paper is to provide a better understanding of the role of productivity on European countries export competitiveness. We use the information compiled in the Trade module of CompNet to establish new stylized facts regarding the joint distributions of the firm-level exports performance and productivity in a panel of 15 countries, 23 manufacturing sectors during the 2000's.

We confirm that exporters are more productive than non-exporters. We also uncover a strong heterogeneity in terms of productivity within the population of exporters, with permanent exporters being much more productive than new starters or firms that stop exporting. This evidence suggests that beyond the entry in the export market, productivity is also an important determinant of firms' survival over a longer time period. From a macroeconomic perspective, this implies that aggregate exports can be supported by the presence of few highly productive firms, which are able to operate in a highly competitive environment.

At the intensive margin, we show that both the level and the growth of firm-level exports rise with firm productivity, and that the bulk of aggregate exports in each country are made by a small number of highly productive firms. In the short run, aggregate exports performance is therefore closely linked to the performance of these firms. Productivity shocks faced by these very large players, such as those related to management practices or to strategic choices regarding the organization of production, have strong influence on the aggregate export performance of European countries.

Finally, we show that during the crisis, the growth of exports by high productive firms sustained the current account adjustment of European "stressed" economies. This last result confirms that the shape of the productivity distribution within each country can have important consequences from the point of view of the dynamics of aggregate trade patterns. 


\section{INTRODUCTION}

Restoring external competitiveness has been at the core of the European policy agenda since the start of the Great Recession in 2008. In a context where current account adjustment in European periphery economies is to a large extent taking place through the contraction of domestic demand and investment, economic growth could be sustained with more dynamic exports. Against this background, the challenge for researchers is to provide policy makers with accurate indicators of (cost or price-based) competitiveness, as well as estimates of the trade elasticities. The achievement of both objectives requires the availability of reliable data sources covering exports and cost or price indicators for European economies.

While the evaluation of competitiveness traditionally relies on macroeconomic indicators such as the Unit Labor Costs (ULCs), previous empirical evidence has shown that they imperfectly predict European countries' export performance. ${ }^{3}$ The research initiated by the Competitiveness Research Network (CompNet), using microeconomic data collected at the firm-level, has shown that the dispersion of the firm-level productivity even within narrowly defined sectors is high (Lopez-Garcia et al., 2014). This result has several implications with respect to the analysis of the sources of export performance. Firstly, traditional competitiveness indicators such as the aggregate ULCs may incorrectly measure the cost and price-competitiveness of exporters, which in some cases represent a small subset of the population of firms. The assessment of competitiveness therefore requires to fully account for the dispersion of productivities within countries and sectors. Secondly, the response of exports to macroeconomic shocks, such as exchange rates variations, or to structural policies in the labor or product markets may depend on the microeconomic characteristics of the sectors in each country.

The objective of this paper is to provide with a better understanding of the role of productivity on European countries export competitiveness. The analysis relies on the information compiled in the Trade module of CompNet, which exploits the richness of a dataset resulting from the merge at the firm level between balance sheet information and trade flows. ${ }^{4}$ This information is used to establish new stylized facts regarding the joint distributions of the firm-level exports performance and productivity in a panel of 15 countries, 23 manufacturing sectors and covering a large number of years mainly in the 2000 's and up to 2012. Key moments of the firm-level productivity or wages distributions are obtained by country, sector and export status (exporter, non-exporter, new exporter, exiter, permanent exporter etc.). We are also able to assess the effect of productivity or size on firm-level exports performance (the intensive margin of exports).

Importantly, all the indicators that are presented in this paper were computed by running a single STATA do-file based on the national firm-level datasets available in the 15 countries that participated to the CompNet's Trade module exercise. This strategy was used in order to avoid statistical discrepancies related to methodological differences, and maximizes the set of indicators that can be used for the cross-country analysis. As in any exercise using firmlevel datasets in a multi-country set-up, the heterogeneity in terms of the representativeness

\footnotetext{
${ }^{3}$ See European Commission MIP scoreboard. Gaulier and Vicard (2013) show for instance that while current account dynamics in the euro area after euro introduction, and before the crisis, were highly correlated with the growth of ULCs and imports, such correlation is less clear on the export side.

${ }^{4}$ See the paper describing in details the CompNet dataset (Lopez-Garcia et al. (2015)).
} 
of the underlying samples may introduce some noise thus limiting the relevance of crosscountry comparisons. This implies that cross-country comparisons should be interpreted with much care. Our contribution here is to provide with an in-depth analysis of the linkages between export performance and productivity at the firm-level for a large set of countries, while previous studies have been mostly focusing on single countries and used unharmonized methodologies. ${ }^{5}$

After a presentation of the code used to generate the harmonized trade and productivity indicators for the 15 countries of the sample, we devote a section to present the underlying firm-level datasets. The summary statistics obtained using the CompNet data confirm that it matches well aggregate export figures, both in terms of levels and growth rates, obtained in each country from different data sources (Eurostat or UN Comtrade).

We provide a series of summary statistics about the population of European exporters, which emphasizes a strong heterogeneity in terms of export shares within the population of exporters. Exporters represent a very substantial share of the population of firms above 20 employees in manufacturing sectors and for most European countries, with half or more of these firms reporting some exports, and a very large share of aggregate employment and turnover within each sector (above $80 \%$ in most countries). This, however, hides a very strong heterogeneity in terms of exports performance within the population of exporters. Aggregate exports are indeed found to be extremely concentrated, with the top 10 exporting firms in each country representing $20 \%$ or more of total exports.

We then compare in a different section how exporters and non-exporters differ in terms of productivity or wages. We confirm that exporters are more productive than non-exporters in each country and industry. This productivity advantage of exporters relative to non-exporters is increasing with export experience, with top exporters or permanent exporters being much more productive than new entrants, exiters or switchers. This confirms previous evidence mostly for single countries that while many firms with low productivity may temporarily export, productivity is an important determinant of survival in the export market in the years after the entry. ${ }^{6}$ We also show that exporters pay higher wages than non-exporters. We do not observe, however, that the population of exporter and non-exporters systematically differ in terms of their labor productivity growth or in terms of wages growth. This analysis is completed with descriptive evidence showing a substantial heterogeneity between exporters and non-exporters in terms of their financial position.

At the intensive margin, we confirm the strong positive relationship between productivity and export performance. In all countries firms in top productivity deciles export, on average, $66 \%$ more than the median firm in terms of productivity, while exports for firms in the lower buckets are about $40 \%$ below the values for the median class. This result implies that the very high concentration of aggregate exports among a small subset of firms is related to the distribution of productivity within countries and sectors, with top productive firms capturing a very large market share. Productivity is also shown to be an important determinant of

\footnotetext{
${ }^{5}$ Importantly, the measure of productivity that is used throughout the exercise is a revenue-based productivity, as we do not observe in this type of data the firm-level prices. This implies that part of the heterogeneity at the micro-level remains unobserved.

${ }^{6}$ An exception is the work by the International Study Group on Exports and Productivity (2008) who provided cross-country evidence specifically focusing on export productivity premia.
} 
exports growth: firms in higher productivity percentiles indeed report higher growth rates in terms of exports values compared to firms in the lower percentiles.

Finally, we explore the role of productivity as a determinant of exports growth during the crisis. We identify a strong heterogeneity in terms of firm-level exports growth across European countries and within countries across firms ranked by their productivity. We find that the growth of exports by high productive firms sustained the current account adjustment of European "stressed" economies relative to other European countries. This positive relation between the strength of current account adjustment and firm-level exports growth is not observed when considering the population of low productive firms in each country. This last result confirms that the shape of the productivity distribution within each country can have important consequences from the point of view of the dynamics of aggregate trade patterns.

If many past research initiatives provide useful information on the dynamic of exports and on the characteristics of exporting firms compared to domestic firms for many countries, the fact that they are based on un-harmonized national databases limit their use for policy and cross-country comparisons. Indeed, if similar stylized facts are observed in many countries (see Ottaviano and Mayer, 2007), cross-country differences in the coverage or the definition of the underlying micro-data become problematic for instance when one starts looking at the distribution of TFP among exporters and non-exporters in order to identify the level of performance required to start export activities. Against this background, the Trade module of the CompNet database is an initiative to provide cross-country comparable indicators computed using a common methodology applied on a set of commonly defined economic variables.

Other initiatives provide information on firm-level based indicators of firms export performance. Among others, the Exporter Dynamics Database managed by the World Bank (Cebeci et al., 2012) provides a detailed description of the various margins of export dynamics at the firm level for a very large set of countries (both developed and developing economies). However, this dataset does not provide any characteristics of the exporting firms in the various countries that could help to better understand the observed dynamics. Another interesting source of information is the results of the EFIGE survey, which provides comparable firm-level information for a small set of EU countries but only for one year (the survey has been conducted in 2010). Also, the International Study Group on Exports and Productivity (2008) provided cross-country evidence specifically focusing on the productivity of exporters relative to non-exporters.

The paper is structured as follows. In section 2, we describe the main structure of the Stata code of the module. Section 3 describes the structure of the various output files produced and discusses the representativeness of firm-level databases that underlie the computation. In section 4, some of the main descriptive results obtained are presented. For instance, we show how exporters contribute to aggregate sector activity in each country, the relative importance of export premia, the intensive margin of exports, the productivity dynamics and the financial position of exporters and non-exporters. Finally, in section 5, we briefly investigate the joint evolution of export growth and productivity during the recent financial crisis. In the concluding section, we also briefly describe the current ongoing research projects that use the rich information produced by the Trade module 


\section{Description Of THE TRADE MOdULE}

As mentioned in the introductory section, the Trade module is an add-on to the CompNet do file that analyzes export behavior of European firms.

In this module, we focus on the exports of goods by manufacturing firms only. ${ }^{7}$ As the main module of the database, it has been run on two samples: the "full sample" that covers all manufacturing firms and the "20E sample" that restricts the sample to firms that have at least 20 employees. The analysis was run considering two definitions of export values. Our first measure of export values is the raw export values recorded either in the annual accounts of the firms or in the intra-EU and extra-EU trade and custom databases. As the second source is subject to country specific time-varying reporting thresholds for intra-EU trade, a second measure of export values has been considered. This alternative measure is a corrected export values that assume a constant reporting threshold of intra-EU trade flows in real terms.

\subsection{STRUCTURE OF THE MODULE}

The Trade module consists of six consecutive parts. It starts with selection and cleaning raw input data and continues with computation of new variables and creation of output data files and charts.

It is run on the subsample of manufacturing firms (NACE rev 2. between 10 and 33) registered in the CompNet do file firm level databases managed by each national institution. ${ }^{8}$ A minimum amount of 1,000 EUR for the export values is required to consider a firm being an exporter. ${ }^{9}$ We also impose that the exports represent at least $0.5 \%$ of the total

\footnotetext{
${ }^{7}$ Some countries analyze total exports of manufacturing firms as they cannot disentangle between exports of goods and exports of services.

8 Sectors included in the analysis are NACE sectors "10. Manufacture of food products", "11. Manufacture of beverages", "12. Manufacture of tobacco products", "13. Manufacture of textiles", "14. Manufacture of wearing apparel", "15. Manufacture of leather and related products", "16. Manufacture of wood and of products of wood and cork, except furniture", "17. Manufacture of paper and paper products", "18. Printing and reproduction of recorded media", "20. Manufacture of chemicals and chemical products, "21. Manufacture of basic pharmaceutical products and pharmaceutical preparations", "22. Manufacture of rubber and plastic products", "23. Manufacture of other nonmetallic mineral products", "24. Manufacture of basic metals, "25. Manufacture of fabricated metal products, except machinery and equipment", "26. Manufacture of computer, electronic and optical products", "27. Manufacture of electrical equipment", "28. Manufacture of machinery and equipment n.e.c.", "29. Manufacture of motor vehicles, trailers and semitrailers", "30. Manufacture of other transport equipment", "31. Manufacture of furniture", "32. Other manufacturing" and "33. Repair and installation of machinery and equipment". Sector "19. Manufacture of coke and refined petroleum products" is not covered.

${ }^{9}$ Note that for countries that use custom or intra-Stat / extra-Stat declarations to observe exports at the firm level, the minimum amount of exports may be much larger (for instance, in Belgium for the 2006-2010 period, intra EU trade is observed for firms exporting to the EU 27 at least 600,000 EUR in a given year).
} 
turnover. ${ }^{10}$ In addition to export values, we also computed exported value added. ${ }^{11}$ We introduce six export status following definitions:

- Exporter $=$ firm with positive export values in $t$;

- Permanent exporter $=$ exporter in $\mathrm{t}-1, \mathrm{t}$ and $\mathrm{t}+1$;

- New exporter $=$ exporter in $\mathrm{t}$ and $\mathrm{t}+1$ but non-exporter in $\mathrm{t}-1$;

- Exiters (from export markets) $=$ exporter in $t-1$ and $t$, but not in $t+1$;

- Temporary exporter $=$ exporter in $\mathrm{t}$ but not in $\mathrm{t}-1$ and $\mathrm{t}+1$;

- Permanent non-exporter $=$ non exporter in $\mathrm{t}-1, \mathrm{t}$ and $\mathrm{t}+1$.

For countries where information on imports is also available, we also define

- Importer = firm with positive import values in $t$;

- Two-way trader $=$ firm with positive export and import values in $t$.

In the Trade module, moments of the distribution of a set of variables ${ }^{12}$ by international trade status have been computed at various level of aggregation.

In addition, the average and median of export values, share of exported turnover, exported value added, share of exporters are computed by productivity deciles (using either TFP, labor productivity). These statistics are also computed by size class. Kernel distributions of export value, exported value added, employment and real value added in 2004, 2008 and 2010 are also generated.

To shed more light on the question whether exporting firms tend to be more productive, the Trade module also includes computation of the productivity premia by international trade status, either considering a non-parametric measure (average or median of a set of productivity related indicators by export status, or correlation between export performance and productivity) or some parametric estimations using regression of log (TFP) on a set of international trade status dummies. Within this module, we also estimate the probability to export on productivity deciles and size class to provide some insights on the probability threshold required to manage export activities.

Finally, some descriptive statistics are computed for a set of additional variables like the share of Top 5 and Top 10 exporters in total exports, the share of Top 60\% exporters and the characteristics of the Top exporters in terms of employment, real value added, etc.

\footnotetext{
${ }^{10}$ As the observed total exports in the custom databases and alike can be larger than the total turnover recorded in the annual accounts, values of exports exceeding $150 \%$ of total turnover have been considered to be misreported and omitted.

${ }^{11}$ Exported value added is obtained by multiplying export values by the valued added / turnover ratio.

12 The list of all variables can be found in Lopez-Garcia et al. (2014).
} 


\subsection{OUTPUT FILES}

The Trade module produces a set of output files. Two different versions of output files are created. The files that have the term "adjusted" in their name use exports values adjusted to changes in reporting threshold for the intra-EU trade. Files that do not have the term "adjusted" in their name use the raw exports values.

Depending on the content, we distinguish three subsets of output files:

General indicators. The files named "Trade_all_countries_sec/countryI_all/20E" provide the moments of the distribution of the variables listed in Lopez-Garcia et al. (2014) for all countries (Trade_all_countries_) at the NACE 2 digit sectoral level (sec) or at the country level (country) for the subsample of all manufacturing firms (all) or of manufacturing firms that employ at least 20 employees (20E) by export status.

Export performance. "Export_performance_by_x_class_all_countries_sec/countryl_all/20E" files provide measures of export performance by class of the $x$ variable. $x$ can be size class (I) , labor productivity class (Iprod), real value added ( $r v a)$ or total factor productivity ( TFP)

Additional trade statistics. Additional results are summarized in the files named "Additional_Trade_Statistics_all_countries_sec/country_all/20E".

Details about the variables included in these files are provided in $\underline{A p p e n d i x ~ D}$.

\section{THE DATASET}

\subsection{COUNTRIES COVERAGE AND FIRM-LEVEL DATASETS}

The results of CompNet's Trade module are available for 15 countries $^{13}$. The list of countries is reported in Table 3.1 with information about the availability of trade variables. Compared to the baseline CompNet sample, we have no international trade variables for Austria, Czech Republic, Germany, Ireland, Latvia and Turkey.

As mentioned above, the source of firm-level international trade data that underlie this project may differ across countries. Some countries rely on customs data and Intra-Stat declarations for intra-EU trade, whereas others use balance-sheet data or Balance of Payments data.

Unfortunately, balance sheet data do not report information about the destination countries. The whole exercise will therefore focus on export status or export values by firms, without consideration for the destination of those exports. This choice allows keeping the largest set of countries in the dataset. Nevertheless, future updates of the Trade module of CompNet could include as well some information about the destination countries, for instance by

\footnotetext{
${ }^{13}$ Even if 15 countries have participated to this module, all countries could not provide information for all the variables in the module. Therefore, based on the analyzed indicator the number of countries available may vary. For instance, imports data are only available for 13 countries.
} 
considering separately intra-EU and extra-EU trade. The firm-level trade datasets are detailed for each country in Appendix A.

A source of cross-country heterogeneity in terms of data coverage is related to differences in the reporting thresholds for trade values in the different datasets. As indicated in Table 3.1 these reporting thresholds are different across countries and they also tend to change over time. In the intra-EU trade data for instance, these thresholds aim at identifying a given proportion of total trade every year ( $97 \%$ for exports and $93 \%$ for imports) ${ }^{14}$. These differences in the reporting thresholds directly affect the average value of exports per firm, which is biased upwards when the threshold value is higher, potentially underestimating the international trade participation of SMEs in some countries.

For this reason, cross-country comparisons in the average levels of exports per firm should be avoided. Within-country comparisons over time should also take into account the changes in reporting thresholds over time, like in the case of New EU Member States at the time of accession in 2004 or in the case of Spain in 2008, which may affect the results. In order to control for changes in the reporting thresholds over time, a second version of the dataset is provided and implements a constant (in real terms) reporting threshold over the whole period.

In most countries, the data cover the most recent years, and the coverage is almost full by the second half of the 2000's. Only for few countries (Belgium, Estonia, France, Slovenia and Spain) the data start in the mid-1990s.

${ }^{14}$ EC regulation $n^{\circ} 6328 / 2004$ amended by EC regulation $n^{\circ} 222 / 2009$, EU Commission regulation $n^{\circ} 1093 / 2013$ and EC regulation $n^{\circ} 659 / 2014$. 


\section{Table 3.1 - Countries coverage and data sources}

\begin{tabular}{|c|c|c|c|c|c|}
\hline Country & $\begin{array}{l}\text { Export } \\
\text { data }\end{array}$ & $\begin{array}{c}\text { Import } \\
\text { data }\end{array}$ & Data source & $\begin{array}{l}\text { Reporting Threshold } \\
\text { (in euros) }\end{array}$ & Coverage \\
\hline BELGIUM & Yes & Yes & $\begin{array}{l}\text { Customs and } \\
\text { intra-stat } \\
\text { extra-stat } \\
\text { declarations }\end{array}$ & $\begin{array}{l}\text { Extra EU exports: All transactions above }>1,000 \\
\text { EUR. } \\
\text { Intra-EU exports: total intra EU exports }> \\
1,000,000 \text { EUR from } 2006 \text { onwards (250,000 from } \\
1998 \text { to } 2005 \text { and } 104,115 \text { EUR before } 1998) \text {. } \\
\text { Intra-EU import: total intra EU imports }>700,000 \\
\text { EUR in } 2010 \text { ( } 400,000 \text { EUR between } 2006 \text { and } \\
2009 \text {, and same threshold as exports before } 2006 \text { ). }\end{array}$ & 1996-2010 \\
\hline CROATIA & Yes & Yes & Balance Sheet & None & $2002-2012$ \\
\hline ESTONIA & Yes & Yes & Customs & $\begin{array}{l}140,000 \text { euros for arrivals and } 100,000 \text { euros for } \\
\text { dispatches, for intra-EU trade in } 2012 \text {. }\end{array}$ & 1995-2012 \\
\hline FINLAND & Yes & Yes & Customs & $\begin{array}{l}\text { Intra-EU imports / exports in euros : } 100,913 / \\
100,913(2000-2001) ; 100,000 / 100,000(2002- \\
2005) ; 100000 / 200000(2006-2007) ; 200,000 / \\
300,000(2008-2010) ; 275000 / 500000(2011- \\
\text { 2012). } \\
\text { Extra-EU: } 1,000 \text { euros until } 2008 \text { and no threshold } \\
\text { 2009-2012. }\end{array}$ & $1999-2012$ \\
\hline FRANCE & Yes & Yes & Customs & $\begin{array}{l}\text { Intra-EU: threshold based on total intra-EU exports } \\
\text { for } \quad \text { the calendar }\end{array} \begin{array}{r}\text { year } \\
38,100 \text { euros }(1998) ; 99,100(2001) ; 100,000 \\
(2002) ; 150,000 \quad(2006) ; \quad 460,000 \\
\text { Extra-EU: } 1,000 \text { euros per transaction }\end{array}$ & $1995-2012$ \\
\hline HUNGARY & Yes & Yes & Customs & $\begin{array}{l}\text { Intra-EU: exports threshold in Million HUFs } 25 \text { for } \\
2004 \text { and } 100 \text { since, for imports } 25 \text { in } 2004,40 \text { in } \\
2005,60 \text { in } 2006-2007,100 \text { million since } 2008 \text {. }\end{array}$ & 2004-2012 \\
\hline ITALY & Yes & Yes & Customs & Annual threshold of 1000 euros & 2001-2012 \\
\hline LATVIA & Yes & Yes & CSB survey & $\begin{array}{l}\text { Variable threshold so that it covers at least } 95 \% \text { of } \\
\text { exports between Latvia and the EU }\end{array}$ & 2005-2012 \\
\hline LITHUANIA & Yes & Yes & Customs & $\begin{array}{l}550,000 \text { LTL for arrivals and } 600,000 \text { LTL for } \\
\text { dispatches, for intra-EU trade in } 2011 \text {. }\end{array}$ & $2000-2011$ \\
\hline MALTA & Yes & Yes & $\begin{array}{l}\text { customs } \\
\text { declarations } \\
\text { and intra-stat } \\
\text { surveys }\end{array}$ & Thresholds of EUR700 & $2005-2011$ \\
\hline POLAND & Yes & No & Balance Sheet & Threshold based on employment: +10 employees & 2005-2012 \\
\hline PORTUGAL & Yes & Yes & Balance Sheet & None & $2006-2012$ \\
\hline ROMANIA & Yes & Yes & $\begin{array}{l}\text { National } \\
\text { Institute of } \\
\text { Statistics }\end{array}$ & None & 2004-2012 \\
\hline SLOVAKIA & Yes & Yes & $\begin{array}{l}\text { Customs, } \\
\text { Balance Sheet }\end{array}$ & $\begin{array}{l}\text { No threshold for exports (source : balance sheets) } \\
\text { Intra-EU threshold for imports for the calendar } \\
\text { year : } 99,582 \text { euros (2004); 165,970 euros (2007); } \\
200,000 \text { euros (2009) (source: customs) }\end{array}$ & 2001-2011 \\
\hline SLOVENIA & Yes & No & $\begin{array}{l}\text { Custom; } \\
\text { Balance sheet }\end{array}$ & $\begin{array}{l}\text { No treshold for the Balance sheet data. For the } \\
\text { Custom data, there are three threshold regimes, in } \\
\text { particular, a zero- threshold for } 2000-2004 \text {, a } \\
\text { treshold of } 22.600 .000 \text { SIT ( 100.000 EUR) for } \\
2004-2007 \text {, and a threshold of } 200.000 \text { EUR for } \\
2007-2012 \text {. }\end{array}$ & $\begin{array}{l}\text { 1995-2012 } \\
\text { for the } \\
\text { Balance } \\
\text { sheet data ; } \\
2000-2012 \\
\text { for the } \\
\text { Custom data }\end{array}$ \\
\hline SPAIN & Yes & Yes & $\begin{array}{l}\text { Balance of } \\
\text { Payments, } \\
\text { CBA, CBB }\end{array}$ & $\begin{array}{l}3.000 € \text { from } 1995 \text { to } 2000 ; 12.500 € \text { from } 2001 \text { to } \\
2007 ; \text { and, finally, } 50.000 € \text { from } 2008 \text { onwards }\end{array}$ & $1995-2011$ \\
\hline
\end{tabular}




\subsection{SAMPLE COVERAGE AND VALIDATION}

As mentioned earlier, results are available for two samples of manufacturing firms. We firstly consider the full population of manufacturing firms (the output datasets are referred to as the All files), or the population of firms with more than 20 employees (the output datasets are referred to as the $20 \mathrm{E}$ files in that case). Most countries provide information for the two samples. However, the All sample does not cover France, Poland and Slovakia, whereas the 20E sample excludes Malta and Spain. Both results for threshold adjusted ${ }^{15}$ and unadjusted trade data are available.

The overall dataset covers 23 NACE 2-digit manufacturing sectors. Exports of goods from non-manufacturing sectors (agriculture and services) are therefore excluded at this stage from the analysis. At the same time, services exports by manufacturing firms are also excluded at this stage. However, data on countries relying on balance sheet export values may contain certain portion of exports of services.

Summary statistics together with aggregate coverage in terms of exports value are reported in the Table 3.2Error! Reference source not found. below. We report the number of exporters per country together with the total number of firms, which allows us computing the share of exporters by country. Note that the number of exporters may be smaller than what could be expected for some countries. This is in a large part due to the fact that we are focusing on firms operating their main activity in manufacturing sectors, and to the impact of the reporting threshold, that it is expected to be higher in those countries with a high proportion of small-sized firms (such as Spain). We also exclude wholesalers and other firms operating in the services industry, but that may also be active in trading goods.

${ }^{15}$ Using constant, in real terms, reporting thresholds for intra EU trade. 
Table 3.2 - Data coverage in terms of the proportion of exporters in 2011

All firms (manufacturing sectors)

\begin{tabular}{|lccccc|}
\hline Country & Nb. Exporters & Nb. Firms & \% exporters & $\begin{array}{c}\text { \% exporters } \\
\text { (Ref. paper) }\end{array}$ & Reference paper \\
\hline BELGIUM & 3,621 & 14,268 & $25.4 \%$ & $23.7 \%$ & Amiti et al. (2012) \\
CROATIA & 2,531 & 9,092 & $27.8 \%$ & & \\
ESTONIA & 1,280 & 4,613 & $27.7 \%$ & $23.9 \%$ & Masso and Vahter (2015) \\
FINLAND & 2,368 & 12,923 & $18.3 \%$ & & \\
HUNGARY & 2,924 & 29,665 & $9.9 \%$ & $27.7 \%$ & Békés et al. (2011) \\
ITALY & 47,151 & 99,593 & $47.3 \%$ & $14.6 \%$ & Secchi et al. (2014) \\
LITHUANIA & 1,513 & 5,418 & $27.9 \%$ & & \\
MALTA & 72 & 212 & $34.0 \%$ & & \\
PORTUGAL & 9,308 & 33,641 & $27.7 \%$ & $28.9 \%$. & Mion and Opromolla (2014) \\
& & & & & \\
ROMANIA & 3,592 & 37,079 & $9.7 \%$ & & \\
SLOVENIA & 2,763 & 5,327 & $51.9 \%$ & $45.8 \%$ & De Loecker (2007) \\
SPAIN & 5,953 & 67,656 & $8.8 \%$ & & \\
\hline
\end{tabular}

More than 20 employees (manufacturing sectors)

\begin{tabular}{|lccccc|}
\hline \multicolumn{1}{|c}{ Country } & Nb. Exporters & Nb. Firms & $\begin{array}{c}\% \\
\text { exporters }\end{array}$ & $\begin{array}{c}\text { \% exporters } \\
\text { (Ref. paper) }\end{array}$ & Reference paper \\
\hline BELGIUM & 2,390 & 3,792 & $63.0 \%$ & $80.3 \%$ & ISGEP (2008)* \\
CROATIA & 1,192 & 1,903 & $62.6 \%$ & & \\
ESTONIA & 714 & 956 & $74.7 \%$ & & \\
FINLAND & 1,401 & 2,333 & $60.0 \%$ & & Ottaviano and Mayer (2007) \\
FRANCE & 10,477 & 18,631 & $56.2 \%$ & $67.3 \%$ & \\
HUNGARY & 2,003 & 4,161 & $48.1 \%$ & & \\
ITALY & 22,650 & 30,967 & $73.1 \%$ & $69.3 \%$ & ISGEP (2008)* \\
LITHUANIA & 1,027 & 1,708 & $60.1 \%$ & & \\
POLAND & 9,297 & 15,192 & $61.2 \%$ & & \\
PORTUGAL & 3,969 & 6,538 & $60.7 \%$ & & \\
ROMANIA & 2,762 & 8,691 & $31.8 \%$ & & \\
SLOVAKIA & 2,064 & 2,549 & $81.0 \%$ & & \\
SLOVENIA & 1,032 & 1,217 & $84.8 \%$ & $81.3 \%$ & ISGEP (2008)* \\
\hline
\end{tabular}

Note: * ISGEP: International Study Group on Exports and Productivity (2008). Based on unadjusted export flows. Data for Belgium are taken in 2010. Compared to official statistics, the lower number of firms and exporters has different sources: (1) calculations are based on manufacturing sectors only thus excluding exporters in services sectors; (2) A minimum amount of 1,000 EUR for the export values is required to consider a firm being an exporter and also impose that the exports represent at least $0.5 \%$ of the total turnover; (3) the algorithm for the correction of outliers implemented in the main program of CompNet is dropping some observations.

The available evidence confirms that larger firms are more likely to export. It is therefore natural to observe that the exporters share is larger when considering the sample of firms with more than 20 employees. Using this sample, a majority of firms export whereas less than half do so if we consider the full population. Most importantly, in a validation 
perspective, the numbers that we obtained are consistent with the exporter share reported in different papers for some countries.

Table 3.3 - Data coverage in terms of exports value in 2011

A. All firms

\begin{tabular}{|lccc|}
\hline Country & $\begin{array}{c}\text { Total exports } \\
\text { value in 2011 } \\
\text { (billion euros) }\end{array}$ & $\begin{array}{c}\text { Total exports } \\
\text { value in 2011 } \\
\text { (Eurostat) } \\
\text { (billion euros) }\end{array}$ & $\begin{array}{c}\% \text { of total } \\
\text { exports value } \\
\text { in Eurostat }\end{array}$ \\
\hline BELGIUM* & 87.5 & 120.0 & $72.7 \%$ \\
CROATIA & 6.2 & & \\
ESTONIA & 5.4 & 6.5 & $82.6 \%$ \\
FINLAND & 40.8 & 38.8 & $105.3 \%$ \\
HUNGARY & 49.5 & 50.3 & $98.4 \%$ \\
ITALY & 269.0 & 295.0 & $91.1 \%$ \\
LITHUANIA & 6.5 & 11.1 & $58.5 \%$ \\
MALTA & 1.4 & 1.7 & $86.2 \%$ \\
PORTUGAL & 27.8 & 28.8 & $96.5 \%$ \\
ROMANIA & 28.5 & 31.9 & $89.3 \%$ \\
SLOVENIA & 15.2 & 13.2 & $115.9 \%$ \\
SPAIN & 89.7 & 132.0 & $68.0 \%$ \\
\hline
\end{tabular}

B. More than 20 employees

\begin{tabular}{|c|c|c|c|}
\hline Country & $\begin{array}{l}\text { Total exports } \\
\text { value in } 2011 \\
\text { (billion euros) }\end{array}$ & $\begin{array}{c}\text { Total exports } \\
\text { value in } 2011 \\
\text { (Eurostat) } \\
\text { (billion euros) }\end{array}$ & $\begin{array}{l}\text { \% of total } \\
\text { exports value } \\
\text { in Eurostat }\end{array}$ \\
\hline BELGIUM & 89.0 & 120.0 & $74.0 \%$ \\
\hline CROATIA & 6.7 & & \\
\hline ESTONIA & 5.9 & 6.5 & $91.5 \%$ \\
\hline FINLAND & 42.9 & 38.8 & $110.8 \%$ \\
\hline FRANCE & 245.0 & 259.0 & $94.6 \%$ \\
\hline HUNGARY & 49.2 & 50.3 & $97.9 \%$ \\
\hline ITALY & 277.0 & 295.0 & $93.8 \%$ \\
\hline LITHUANIA & 6.6 & 11.1 & $59.3 \%$ \\
\hline POLAND & 89.3 & 93.1 & $95.9 \%$ \\
\hline PORTUGAL & 26.8 & 28.8 & $93.3 \%$ \\
\hline ROMANIA & 28.6 & 31.9 & $89.8 \%$ \\
\hline SLOVAKIA & 36.7 & 37.1 & $98.9 \%$ \\
\hline SLOVENIA & 15.6 & 13.2 & $118.7 \%$ \\
\hline
\end{tabular}

Note: Based on unadjusted export flows. CompNet data are taken in 2010 for Belgium. In some cases (Finland or Slovenia), the coverage in terms of total exports is above $100 \%$. This inconsistency can be explained by the differences in the micro data sources between CompNet and Eurostat data, or differences in the industry classification of firms. Eurostat exports are used as a reference for both the All and $20 \mathrm{E}$ sample. The representativeness of the 20E sample may be higher than the full sample. This discrepancy is due to the fact that $20 \mathrm{E}$ sample observations are weighted to improve the overall representativeness. Please refer to the CompNet paper (Lopez-Garcia et al. (2015)) for more details about the sample weights. 
Not surprisingly, the exporter share is also larger for geographically smaller countries (Latvia and Slovenia All samples potentially cover the whole populations of firms). In the case of Italy, the high share of exporters is a consequence of the exclusion, from the population of reference, of self-employed firms and unlimited partnerships that are mainly concentrated in the micro-sized class 1-9 workers with a very low level of export (less than $5 \%) .{ }^{16}$ In the case of Spain, the very small proportion of exporters $(8.8 \%)$ compared to other similar countries can be explained by the reporting threshold in the Balance of Payment statistics, which is excluding some SMEs from the population of exporters.

We also provide in Table 3.3 a validation of our data in terms of the coverage of aggregate exports reported in aggregate statistics. Eurostat indeed reports information about exports by firms operating in manufacturing in $2011 .{ }^{17}$ We therefore use this year as a benchmark in order to compare the total value of exports we observe with the official figure. The results reported confirm that our samples cover a large fraction of aggregate countries exports. ${ }^{18}$ In Spain, although only $8.8 \%$ of the population of exporters is reported as exporting, the total value of exports still represents $68 \%$ of the official figure reported in Eurostat. This implies that our database still has a good coverage of the population of large exporters for Spain. In other countries, the coverage rate is equal or above $80 \%$ of aggregate exports.

A first conclusion from these comparisons is that although the coverage of the CompNet Trade module is rather good in terms of aggregate exports, the share of exporters is heterogeneous across countries. This pattern reflects both economic realities in each country and differences in terms of the reporting thresholds, which are listed in Table 3.1.This selection is affecting the presence of small exporters in the raw datasets, and consequently the average value of exports by firm in each country and the average size of these firms.

The evolution of aggregate exports data observed in our datasets can also be compared with the evolution observed in different datasets. Unfortunately, the Eurostat data used to compare aggregate levels in 2011 are only available for a single year. We use instead as a benchmark the trade data provided by the CEPII-BACI dataset. ${ }^{19}$ This data provides information on export values and quantities by country pairs, 6-digit products of the Harmonized Commodity Description and Coding System and years. This allows us identifying goods that are usually produced by manufacturing industries. With this strategy, we end-up with aggregate exports data of manufacturing goods by country. The levels could slightly differ from the CompNet trade data, since some of these goods could be exported by wholesalers or firms operating in services. We expect, however, that the evolutions are more comparable. Results of these comparisons are reported in Figure 3.1. They confirm our

\footnotetext{
${ }^{16}$ For Italy the population of reference is represented by the subset of Limited Liability Companies with employees (501,494 units in the Business Register in 2012, of which 110,749 operating in manufacturing activities); the coverage is $86 \%$ in terms of units, $90 \%$ in terms of employment and $91 \%$ in terms of exports. From this sub-population were excluded Sole proprietorships, Partnerships and other Limited Liability Companies without employees - about 3.8 million of units. See Appendix A. For Portugal, sole proprietorships are not included in the survey as well. This is one of the reasons why the representativeness of the number of employees is relatively weaker.

${ }^{17} \mathrm{http}: / /$ epp.eurostat.ec.europa.eu/newxtweb/setupdimselection.do

${ }^{18}$ Note that the percentage of exports covered in both samples are not directly comparable, since the program used for the 20E sample uses population weights.

${ }^{19} \mathrm{http}: / /$ www.cepii.fr/cepii/fr/bdd_modele/presentation.asp?id=1
} 
expectations that the evolution of the trade values in our dataset matches quite well the evolution of aggregate exports reported in BACI.

\section{Figure 3.1 - Evolution of aggregate exports in CompNet trade data and BACI}

A. Full sample

Exports index (index $=1$ in 2008)

(Sample: All)

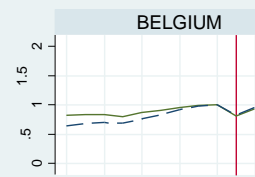

HUNGARY

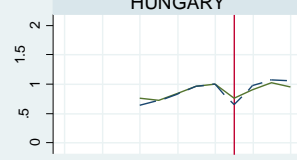

PORTUGAL

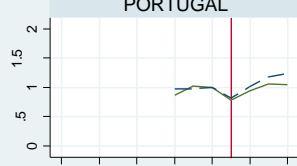

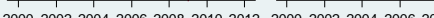

Exports CompNet

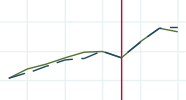

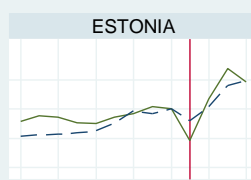

LITHUANIA

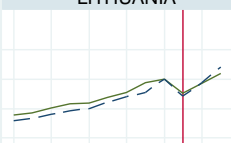

SLOVENIA

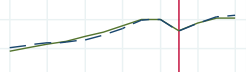

\section{----- Exports BACl}

Graphs by country

B. Firms with more than 20 employees

Exports index (index $=1$ in 2008)

(Sample: 20 employees)

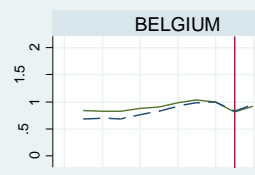

HUNGARY

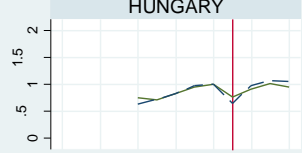

PORTUGAL

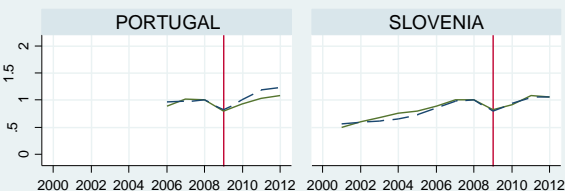

Exports CompNet

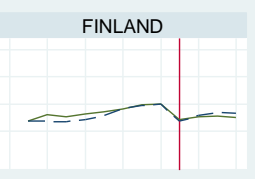

LITHUANIA

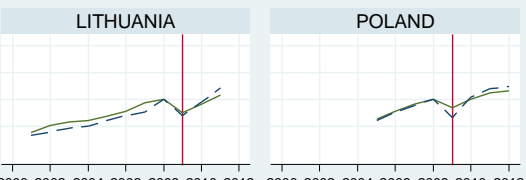

20002002200420062008201020122000200220042006200820102012

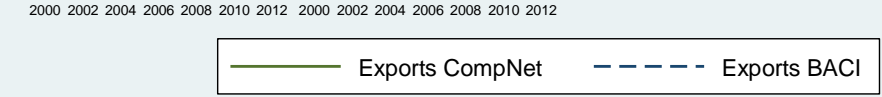

Graphs by country 


\section{DESCRIPTIVE STATISTICS ABOUT THE POPULATION OF EXPORTERS ${ }^{20}$}

\subsection{SHARE OF EXPORTERS IN AGGREGATE LABOR AND SALES}

How much of the economic activity is made by exporters? One of the benefits of the CompNet Trade module is that it brings detailed information on the population of firms divided into several categories (exporters, non-exporters, new exporters etc.). We provide in Table 4.1 a summary statistics regarding the share of exporters in total employment, labor costs, real value-added and turnover. These statistics rely on the $20 \mathrm{E}$ sample within each country, with the exception of Spain and Malta where only the full sample is available.

The share of exporting firms in total employment, as reported in Table 4.1 is high. For instance, in 2010, it represented $54 \%$ of manufacturing employment in Romania, and up to $90 \%$ in Slovakia. This confirms that not only exporters represent a large proportion of firms in manufacturing sectors (see Table 3.2), but also that a majority of workers are directly involved into exporting activity. Although taking into account the full sample tends to reduce this share (see for instance Spain), exporters still represent a very substantial role in total employment. Their share in total labor costs is also very substantial (almost $80 \%$ on average). Interestingly, the share of exporters in terms of the real value-added or turnover is even larger. This is a first sign, which will benefit from an in-depth analysis below, that exporters are also generally more productive than non-exporters.

\footnotetext{
${ }^{20}$ The indicators presented in this section cover at most 15 countries. Because some indicators could not be computed or were not comparable for some countries due to representativeness issues for some particular years, the country coverage of the different graphs and tables may differ across the sub-sections. Note also that the data used for Spain and Malta are based on the 'all' files in absence of the 20E files. Therefore, comparison with other countries should be made with very much care.
} 
Table 4.1 - Share of exporters in employment, labor costs, real value added and turnover (country level)

\begin{tabular}{|lllllllll|} 
& \multicolumn{2}{c}{ Employment } & \multicolumn{2}{c}{ Labor costs } & \multicolumn{2}{c|}{ Real value added } & \multicolumn{2}{c|}{ Turnover } \\
& 2006 & 2010 & 2006 & 2010 & 2006 & 2010 & 2006 & 2010 \\
\hline BELGIUM & 0.81 & 0.80 & 0.84 & 0.82 & 0.85 & 0.85 & 0.90 & 0.88 \\
CROATIA &. & 0.80 &. & 0.84 &. & 0.87 &. & 0.88 \\
ESTONIA & 0.80 & 0.82 & 0.83 & 0.84 & 0.85 & 0.88 & 0.87 & 0.93 \\
FINLAND & 0.84 & 0.80 & 0.86 & 0.84 & 0.91 & 0.89 & 0.93 & 0.90 \\
FRANCE & 0.75 & 0.75 & 0.80 & 0.79 & 0.81 & 0.80 & 0.85 & 0.85 \\
HUNGARY & 0.64 & 0.70 & 0.74 & 0.78 & 0.78 & 0.80 & 0.88 & 0.90 \\
ITALY & 0.82 & 0.84 & 0.85 & 0.86 & 0.86 & 0.88 & 0.87 & 0.89 \\
LITHUANIA & 0.66 & 0.69 & 0.71 & 0.76 & 0.76 & 0.81 & 0.82 & 0.88 \\
MALTA* & 0.71 & 0.66 & 0.65 & 0.71 & 0.73 & 0.70 & 0.85 & 0.82 \\
POLAND & 0.79 & 0.79 & 0.82 & 0.82 & 0.85 & 0.83 & 0.86 & 0.86 \\
PORTUGAL & 0.72 & 0.74 & 0.75 & 0.77 & 0.78 & 0.80 & 0.84 & 0.85 \\
ROMANIA & 0.48 & 0.54 & 0.56 & 0.64 & 0.55 & 0.68 & 0.66 & 0.74 \\
SLOVAKIA & 0.90 & 0.90 & 0.91 & 0.92 & 0.95 & 0.93 & 0.94 & 0.94 \\
SLOVENIA & 0.86 & 0.88 & 0.89 & 0.91 & 0.91 & 0.93 & 0.94 & 0.95 \\
SPAIN* & 0.53 & 0.48 & 0.63 & 0.58 & 0.66 & 0.62 & 0.72 & 0.69 \\
\hline Average & 0.74 & 0.75 & 0.77 & 0.79 & 0.80 & 0.82 & 0.85 & 0.86 \\
\hline
\end{tabular}

Note: * calculations based on adjusted exports in the 20E sample, except for Malta and Spain where the full sample is used. In the case of Spain, changes in the reporting thresholds by 2008 explain part of the evolutions reported in this table between 2006 and 2010.

A sector breakdown (provided in Appendix B) shows that exporting firms' prevalence is highest in the manufacturing sector of basic metals. The lowest share of exporting firms is in the sector of repair and installation of machinery. On average (across all countries) the two sectors represent extremes also in terms of the exporters' contribution to the analyzed performance indicators. Exporting firms create $94-95 \%$ of value added or turnover in the sector of basic metals and account for more than $90 \%$ of employment in this sector. On the other hand, in the sector of repair and installation of machinery, they create $40-45 \%$ of value added or turnover and employ $40 \%$ of employees.

\subsection{EXPORTS INTENSITY OF EUROPEAN FIRMS}

In addition to exporters' contribution to some economic indicators, further interesting information can be extracted from a more detailed analysis of exports intensity of European firms, measured using the ratio of export value over turnover.

Among the population of exporters, export sales represent about $45 \%$ of the total turnover, with a median share above $40 \%$. This number is above $65 \%$ in the case of Estonia and Hungary, two small open economies. This evidence, together with the very high share of employment by exporters in these countries, implies that a very substantial share of their economic activity in the manufacturing sectors is related to exports. This is also consistent with other evidence highlighting the strong integration of these economies and other European Union new Member States into global value chains (GVCs), especially with other 
EU countries (see De Backer and Miroudot, 2014). Conversely, exports represent a smaller share of total turnover in the case of larger "old" EU countries such as France or Italy (less than $30 \%$ on average).

\section{Table 4.2 - Export intensity (at the country level)}

\begin{tabular}{|lcccc|} 
& \multicolumn{2}{c}{ Median export ratio } & \multicolumn{2}{c|}{ Mean export ratio } \\
& 2006 & 2010 & 2006 & 2010 \\
\hline BELGIUM & 0.54 & 0.52 & 0.52 & 0.51 \\
CROATIA &. & 0.35 &. & 0.43 \\
ESTONIA & 0.56 & 0.65 & 0.56 & 0.60 \\
FINLAND & 0.32 & 0.32 & 0.37 & 0.38 \\
FRANCE & 0.23 & 0.24 & 0.30 & 0.31 \\
HUNGARY & 0.64 & 0.66 & 0.61 & 0.62 \\
ITALY & 0.28 & 0.29 & 0.34 & 0.35 \\
LITHUANIA & 0.52 & 0.57 & 0.51 & 0.54 \\
MALTA* & 0.62 & 0.46 & 0.60 & 0.48 \\
POLAND & 0.28 & 0.28 & 0.39 & 0.39 \\
PORTUGAL & 0.32 & 0.32 & 0.41 & 0.41 \\
ROMANIA & 0.39 & 0.53 & 0.48 & 0.54 \\
SLOVAKIA & 0.58 & 0.61 & 0.55 & 0.57 \\
SLOVENIA & 0.50 & 0.52 & 0.51 & 0.51 \\
SPAIN* & 0.10 & 0.11 & 0.19 & 0.19 \\
\hline Average & 0.42 & 0.43 & 0.45 & 0.46 \\
\hline
\end{tabular}

Note: * calculations based on adjusted exports in the 20E sample, except for Malta and Spain where the full sample is used. Due to the 20E sample, the shares of top exporters are higher than in the Finnish Customs reports. 


\section{Box 1: Changes in the distribution firm-level export ratios}

Whereas the export propensity of firms remains quite stable over time in the case of "old" EU Member States, more visible changes in mean export ratios took place in new EU members. The greater trade openness of these economies over time is materialized by a change in the distribution of the exports ratios, with the median export ratio growing quite substantially over the period 2006-2010. This change is especially visible in Romania and Estonia, where firms now rely more on external markets than they used to in the mid 2000 's. This pattern may be the result of the EU accession, which affected firms' exports through different channels such as trade policy or greater flows of foreign direct investments. Testing for the relative importance of these different channels though would require implementing more specific tests.

Also, the exports ratio at the bottom of the distribution appears as more stable. This pattern can be explained by the flows of new entrants every year, which start by exporting small amounts before growing in external markets if they are profitable enough. A rise of this export ratio, if it is not related to changes over time in the reporting thresholds for exports, may signal an increase in the barriers to entry, or a tougher competition in international markets.

\section{Figure 4.1 - Distribution of export ratios by country}

Shifts in distributions of export ratio
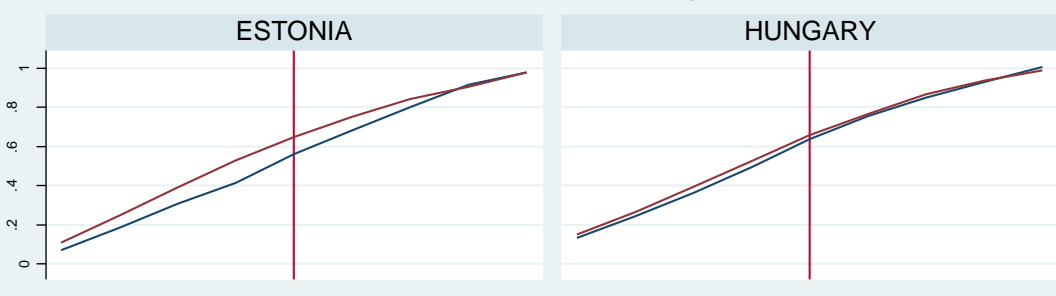

LITHUANIA
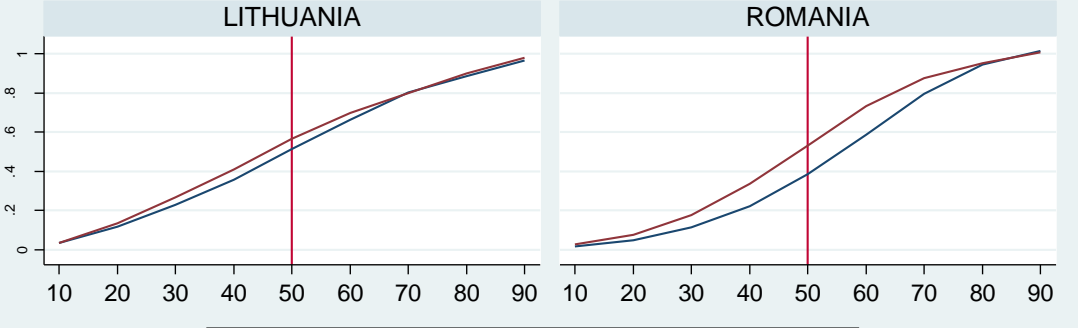

2006 distribution

CompNet dataset (year 2010), Adjusted sample 20e (except Spain and Malta)

\subsection{SHARE OF TOP EXPORTERS}

Country-level exports are generally concentrated among a small subset of firms (see Ottaviano and Mayer, 2007). Our results confirm this empirical pattern for our set of countries, although with quite a substantial heterogeneity. We report in Figure 4.2 the share of country-level exports that is made by the top 5 or top 10 exporters. Naturally, this share is very high for small countries, such as Malta or Slovakia, where the top 10 exporters 
represent $90 \%$ and $50 \%$, respectively, of the total exports. The share of the top exporters in total exports is also substantial in larger countries such as France, Poland and Italy, where the share of the top 10 exporters is close to $20 \%$ or above.

This result has clear implications in terms of the analysis of countries export competitiveness. Gabaix (2011) shows that in the presence of a fat-tailed distribution of firm sizes, idiosyncratic shocks affecting large firms have a significant impact on macroeconomic outcomes. Accordingly, in the presence of a large concentration of exports among a small set of firms, productivity shocks faced by top exporters could have important consequence on aggregate export performance. This is one of the reasons why traditional aggregate competitiveness indicators such as the Unit Labor Costs (ULCs) are not necessarily adequate indicators of the cost-competitiveness, as the dynamics of productivity and wages for the whole economy may differ from that among the few top exporters.

\section{Figure 4.2 - Share of top exporters on total country-level exports (2008)}

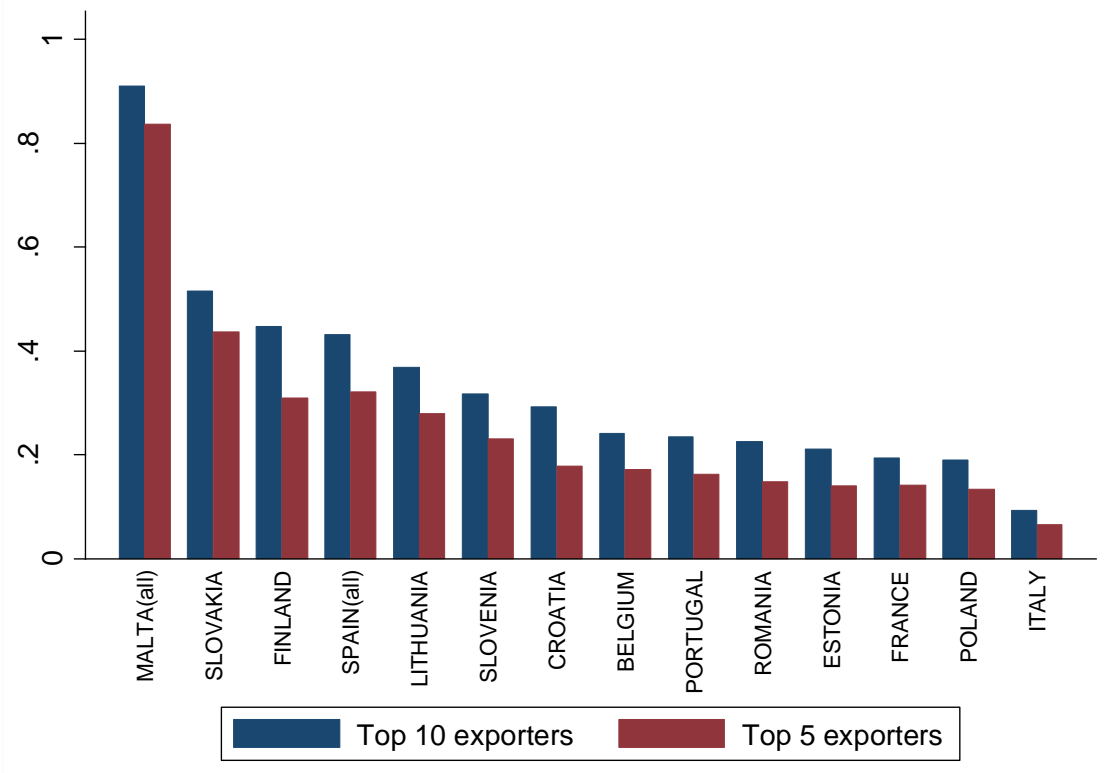

Note: calculations based on adjusted exports in the 20E sample, except for Malta and Spain where the full sample is used.

Beyond the size of countries, the patterns of their specialization may also affect the concentration of their exports. Figure 4.3 presents the average concentration of exports activity by sector. The concentration of exports within-sector is on average higher than for the whole economy. The concentration of exports among the top 10 exporters ranges from slightly more than $40 \%$ in fabricated metals, to more than $90 \%$ in tobacco products. Overall, this implies that the specialization of countries into sectors with a high degree of concentration of exports, such as in the production of cars and other transport equipment, would tend to increase the overall concentration of exports due to a composition effect. 


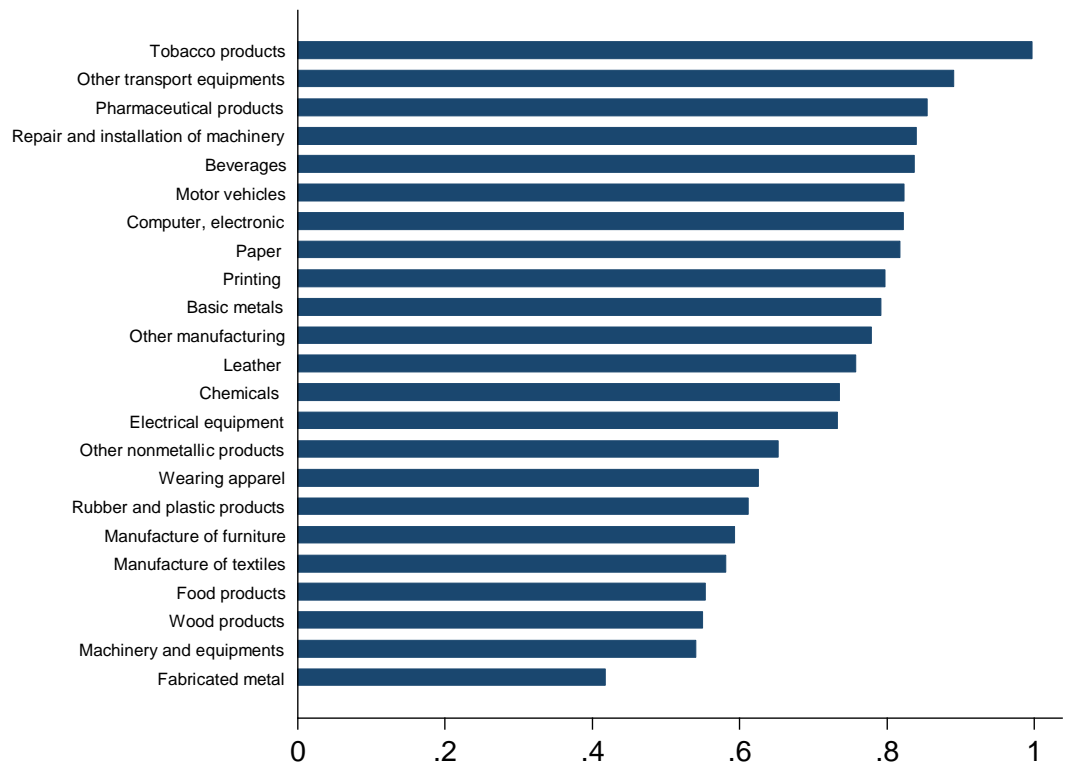

Note: calculations based on adjusted exports in the 20E sample, except for Malta and Spain where the full sample is used.

\section{EXPORTERS VERSUS NON EXPORTERS: PRODUCTIVITY, WAGES AND FINANCIAL POSITION}

\subsection{THE PRODUCTIVITY AND WAGES OF EXPORTERS RELATIVE TO NON-EXPORTING FIRMS}

In this subsection, we investigate differences in the performance of exporting and nonexporting firms. It is a well-established fact from the empirical literature that exporting firms have on average higher productivity or pay higher wages (Bernard and Jensen, 1999). However, the existence of learning by exporting, whereby firm-level productivity would improve consecutive to starting exporting, is more debated in the empirical trade literature. No such evidence appears in the seminal paper by Bernard and Jensen (1999) in OLS estimations where the current productivity of firms is explained by their initial export status, suggesting that the higher productivity of exporting firms is due to self-selection.

We conduct in this section an investigation of the productivity of exporters relative to nonexporters (so called "export premia") in $14 \mathrm{EU}$ countries. ${ }^{21} \mathrm{~A}$ similar exercise conducted by considering wages and firm size is presented in Appendix. The export premium is calculated as non-parametric measure where the performance of exporting firms in an industry is

$21 \quad$ Malta is not included in that analysis. Productivity is measured as real value added per employee. We also computed TFP export premia presented in Appendix. 
compared to the performance of non-exporting firms in the respective industry. Results are reported as industry-averages by country and year. Industries (defined at NACE 2-digit level) that have less than ten exporters are excluded.

\section{Figure 5.1 - Export premia in labor productivity (2004-2012)}

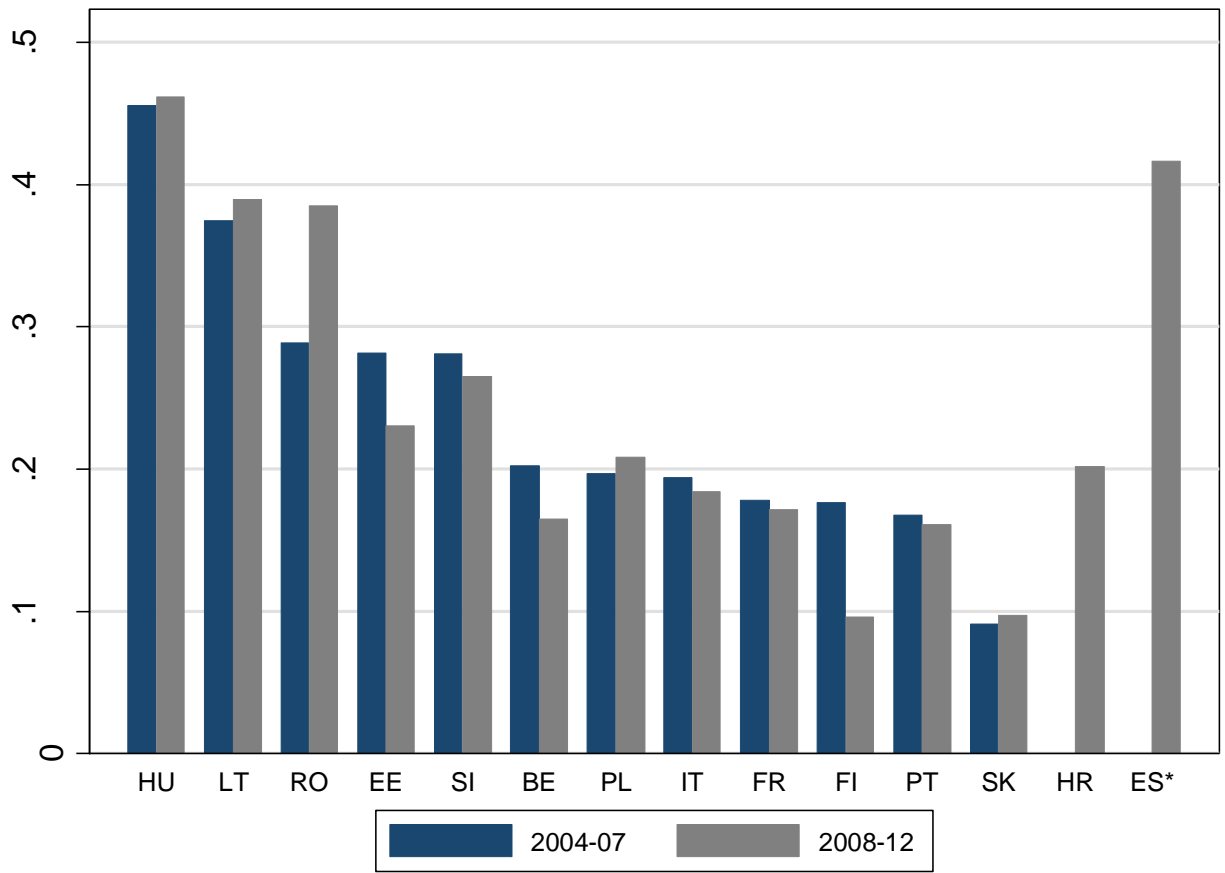

Note: Labor productivity is calculated as real value added per employee from intra-EU trade adjusted sample. Export premia in $\%$ are calculated as log differences in labor productivity of exporters and non-exporters in the same industry. Industry-level values are transferred to the country-level by taking simple un-weighted average over industries. Industries with less than 10 exporters are excluded, which corresponds to around 3\% of industry*year observations. Data for Poland are from 2005, for Portugal from 2006, and for Spain and Croatia from 2008. Data for Belgium are available up to 2010 and for Lithuania, Slovakia and Spain up to 2011. Data for Spain are not adjusted for reporting thresholds.

Results presented in Figure 5.1 confirm that European exporting firms are more productive than purely domestic firms. The productivity premium of exporters shows substantial heterogeneity across countries. Exporters are about 20\% more productive than nonexporters in European countries such as Belgium, Poland, Italy, France, Finland, Portugal, or Croatia. The higher productivity premium of exporters in some Central and Eastern European countries such as Hungary, Lithuania, Romania, Estonia and Slovenia may be related to the strength of foreign direct investment over the past two decades, and the integration of local firms into European supply chains, which pulled internationalized firms' productivity towards higher levels. In the case of Spain, the comparability of the productivity premium of exporters with other countries is limited due to differences in terms of the underlying firmlevel samples, and also due to the change in terms of the declaration threshold for Spain in 2008, which increases the representativeness of large firms relative to small ones. Overall, the higher productivity of exporters relative to non-exporters confirms, for a large set of 
European countries and recent data, previous findings in the literature using difference samples of countries. ${ }^{22}$

\section{Figure 5.2 - Export premia in labor productivity over export status (2004-2012)}

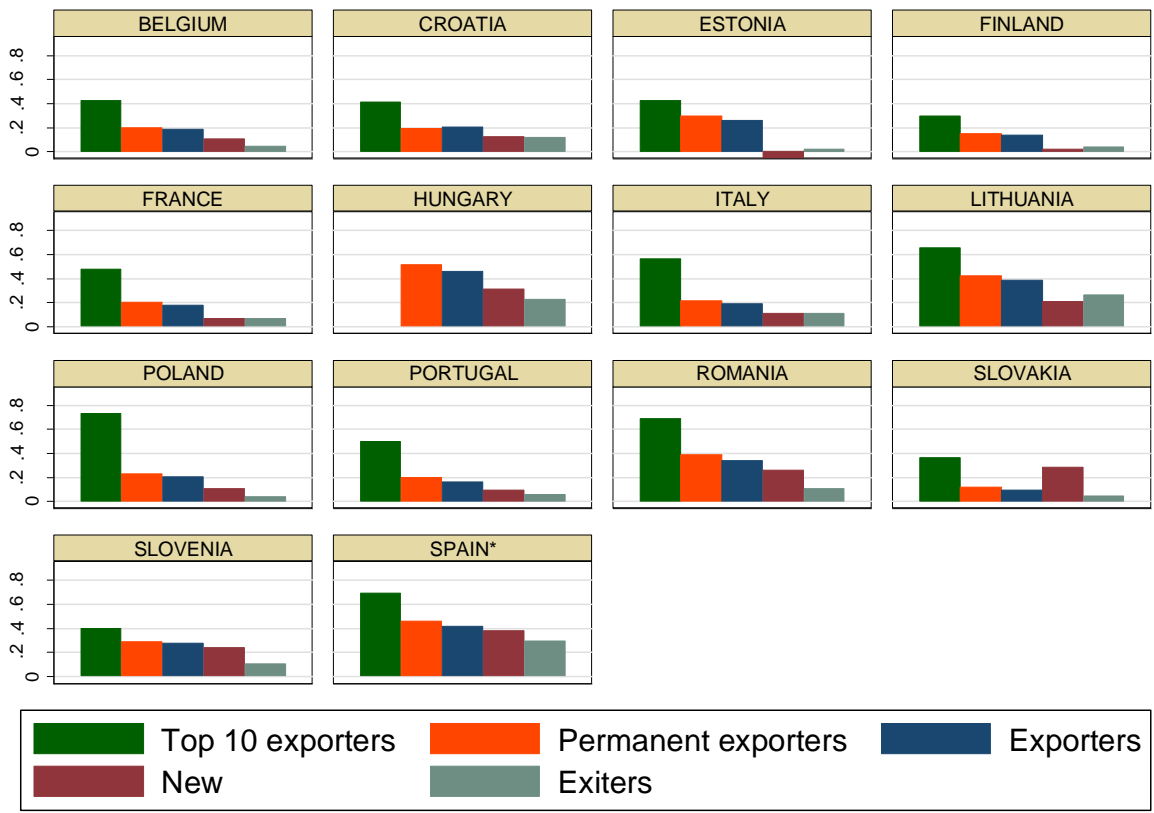

Note: Please see also notes on Figure . Export statuses are defined as in Section 2.1. Spanish data go up to 2011 and are not adjusted for reporting thresholds.

In Appendix C, we also present export premia in TFP, wages and employment. In Figure C.1 we confirm the higher productivity of exporters when using TFP instead of labor productivity. The results presented in Figure C.2 also confirm that exporters pay higher wages than nonexporters in all countries. Interestingly, the exporting premia in wages are lower than in labor productivity, suggesting that among exporters the remuneration of capital represents a higher share of value-added than among non-exporters. Finally, exporters appear, as expected, much larger than non-exporters regardless the country (Figure C.3).

The above simple non-parametric approach provides a comparative analysis of labor productivity differences between exporters and non-exporters. It is complemented by the results presented in Figure 5.2 where we consider in addition the export experience of firms, thus differentiating top exporters or permanent exporters from newcomers or exiters. By so doing, we expect to provide a complete picture of the linkages between productivity and export activity, and provide some new piece of evidence regarding to how higher

22 Comparative firm-level study by ISGEP (2008) finds the labor productivity premium to be lower than we do, around $10 \%$ for Belgium, Italy and Slovenia. This difference with our results is explained by the differences in terms of the empirical methodologies employed. While in our case we simply employ a non-parametric approach and simply take the ratio of exporters labor productivity relative to non-exporters within an industry, they use an econometric approach that control for industry effects, firm size and wages. 
productivity may help firms enter into exports. Based on this figure, some stylized facts emerge.

First, there is a high dispersion in productivity among the population of exporters. The top exporters are notably more productive than the average exporters in all countries (up to $70 \%$ more productive than non-exporters). Second, there is evidence that export entrants are more productive than non-exporters, but, in most countries, they are also remarkably less productive than the average exporter. Overall, the most intriguing result in this section is that the productivity premium of exporters relative to non-exporters tends to increase with the export experience of firms. All these facts hold also for the TFP premia (see Figure C.1 and Figure C.4) and for most of the countries also for premia at the country level (see Figure C.5).

This pattern is consistent with two mechanisms related to the export activity. One is related to the so-called learning by exporting whereby firms tend to learn about market conditions over time, which increases their productivity. The other mechanism is related to firm selection into export market: while starting exporting to nearby markets is relatively easy for firms, exporting more permanently and to more difficult market requires a higher level of productivity. Although the learning mechanism has found only limited support in the empirical trade literature (see De Loecker, 2007, for Slovenia), there is ample evidence that selection mechanisms are important in determining these productivity premia (Wagner, 2012), with the probability of survival increasing rapidly with the number of years spent in the export market (Berthou and Vicard, 2013, Eaton et al., 2007, Freund and Pierola, 2010).

Is there a cutoff productivity level above which export participation increases dramatically? While theoretical models with heterogeneous firms such as Melitz (2003) or Chaney (2008) predict that the population of exporters and non-exporters can be differentiated with a clear productivity threshold below which firms cannot profitably export, our results in Figure 5.3 suggest rather that the share of exporters is progressively increasing with the firm-level productivity. Indeed, we cannot identify any breaking point in the productivity distribution where the share of exporters rapidly increases.

One implication of this result is that external shocks affecting competitiveness, such as a depreciation of the exchange rate, may affect the decision to export of a wide diversity of firms characterized by both high and low productivity levels. The reaction of firms at the extensive margin may therefore be more important than what theoretical models with heterogeneous firms actually predict. $^{23}$

\footnotetext{
${ }^{23}$ In these models, such as Melitz (2003), only firms around the productivity threshold are expected to be affected by external shocks such as variations in the foreign demand or exchange rates movements. In this set-up, how aggregate trade flows are affected by the extensive margin of exports therefore depends upon the shape of the productivity distribution within the country and sector (di Mauro and Pappada, 2014).
} 


\section{Figure 5.3 - Share of exporters over labor productivity deciles (2004-2012)}
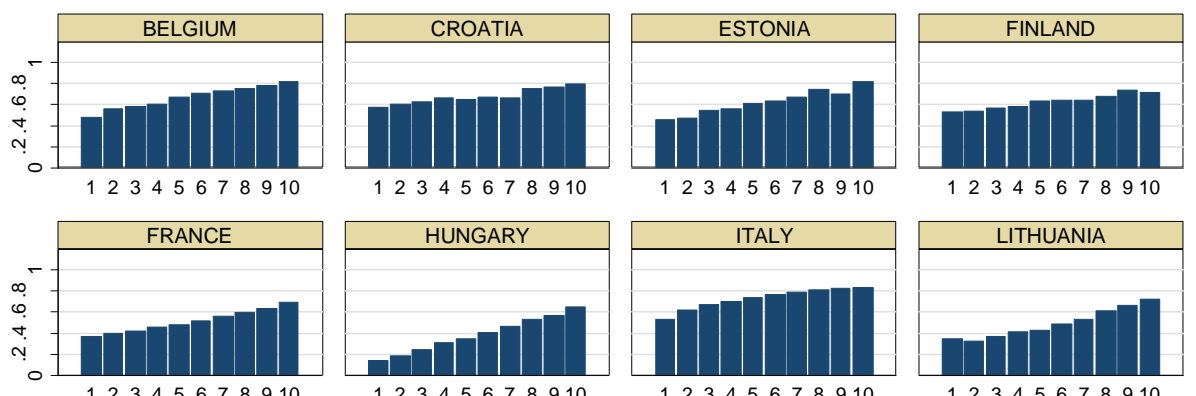

12345678910

1233456788910
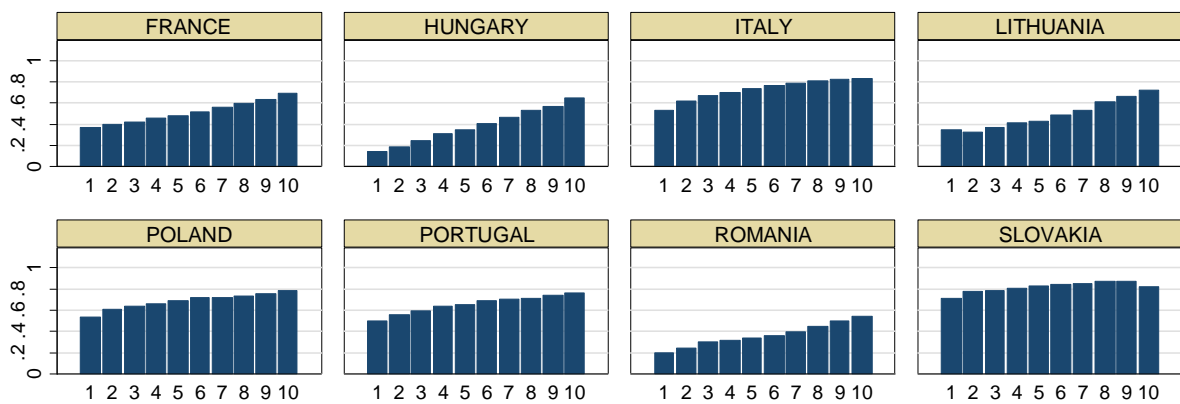

123456789910

12345678910

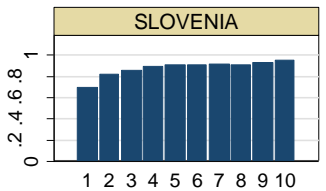

Numbers from 1 to 10 refer to labour productivity deciles

Note: Please see also notes on Figure .

\subsection{THE DYNAMICS OF WAGES AND PRODUCTIVITY FOR EXPORTERS VERSUS NON-EXPORTERS}

We now focus our attention on the dynamics of wages per worker and productivity, which are both key indicators of competitiveness. The value-added of the CompNet data in its Trade module is that it allows identifying the contribution of exporters and non-exporters to the dynamics of these two variables, whereas national account cannot make this distinction. On the one side, making the distinction between exporters and non-exporters allows identifying the changes in terms of cost competitiveness for the population of firms that is exposed to international competition and contribute directly to aggregate exports. On the other side, the dynamics of productivity and wages for non-exporters also brings valuable information, as these firms may also contribute indirectly to aggregate exports, either because they export indirectly through wholesalers or because they supply inputs to final goods firms which then export. 


\section{Figure 5.4 - Growth rate of wages per worker}
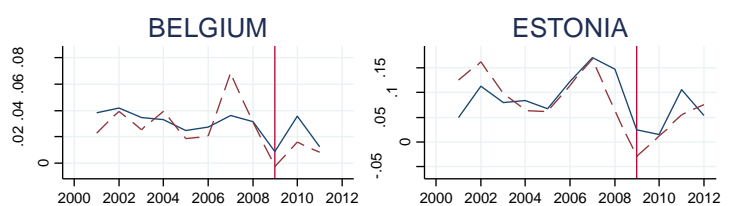

FINLAND
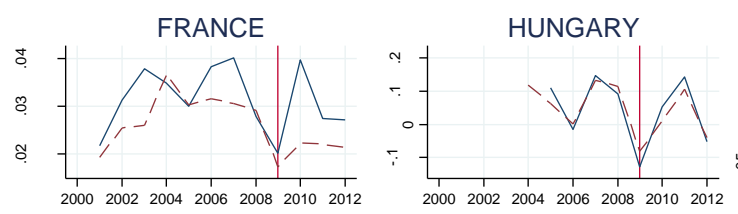

2000200220042006200820102012

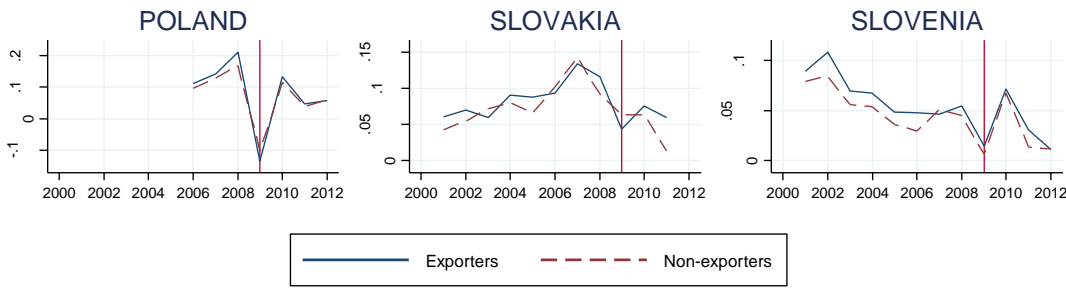

Note: Graph obtained using the sample with more than 20 employees and harmonized thresholds, at country-level.

\section{Figure 5.5 - Distribution of the growth rate of wages per worker (p10 to p90) in 2007}
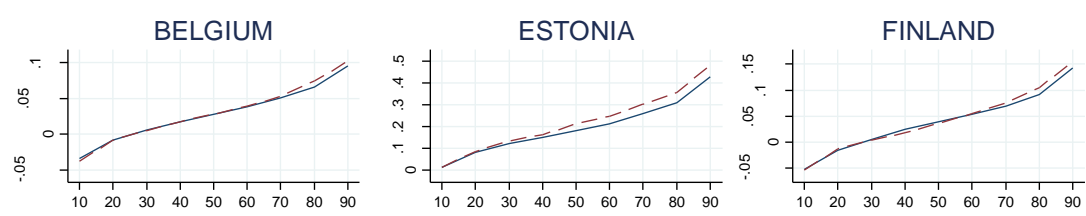

FRANCE
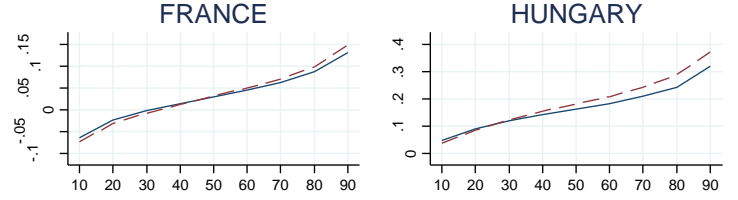

ITALY
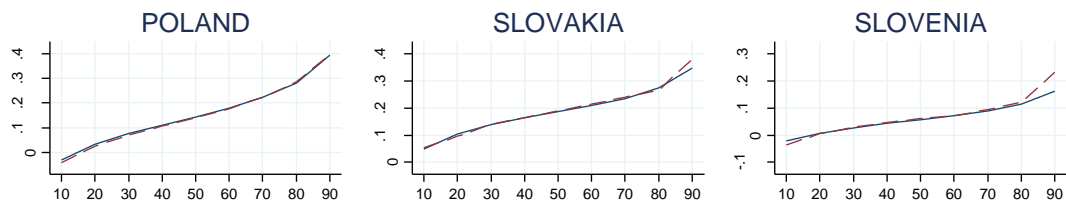

Exporters

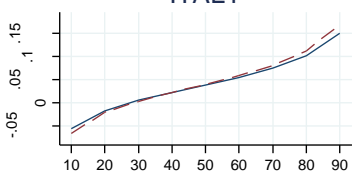

SLOVENIA

Note: Graph obtained using the sample with more than 20 employees and harmonized thresholds, at country-level. 
Figure 5.4 depicts the growth rate of the weighted mean of wages per worker distinguishing between exporting and non-exporting firms. For most countries, the period of the trade collapse in 2009 is marked by a strong decline in the growth of wages for both exporters and non-exporters (Finland is an exception). Overall, no clear difference in terms wage growth can be observed between exporters and non-exporters, except for some countries such as France. This observation is comforted by the distribution of wage growth in Figure 5.5. With the exception of Estonia and Hungary where the growth of wages is more pronounced for exporters than for non-exporters, the shape of the distributions for the two populations of firms is very similar for the rest of the countries.

\section{Figure 5.6 - Growth rate of mean Labor productivity}
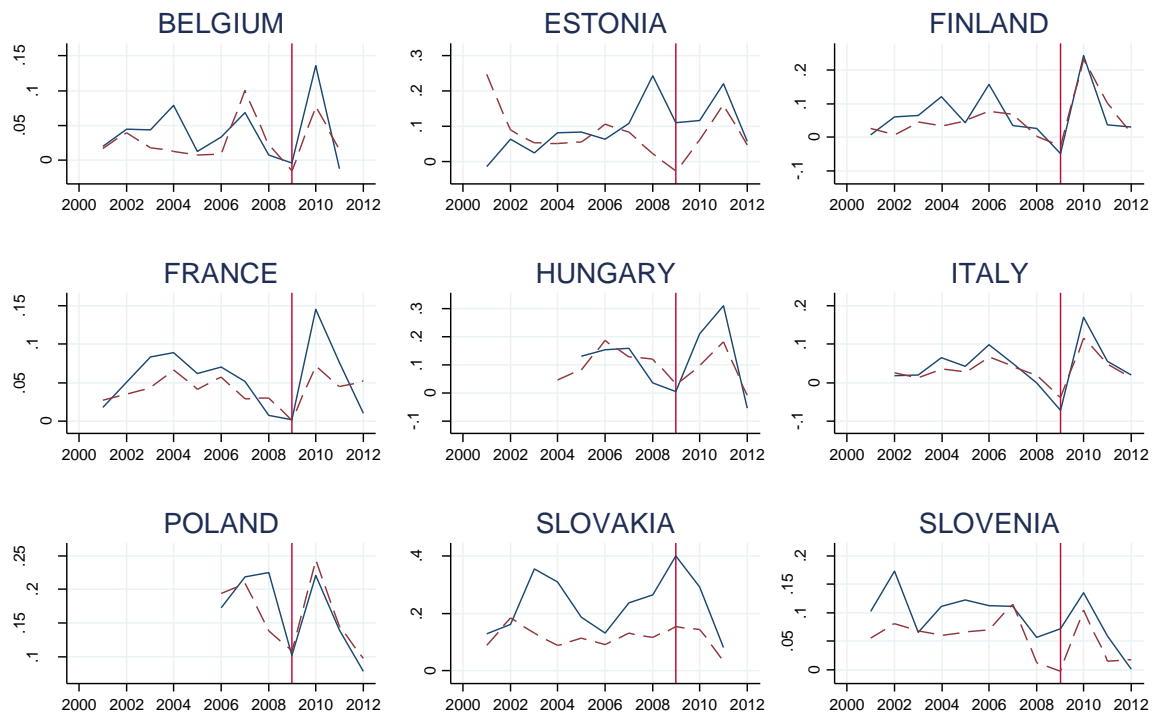

Exporters $\quad-----$ Non-exporters

Note: Graph obtained using the sample with more than 20 employees and harmonized thresholds, at country-level. 


\section{Figure 5.7 - Distribution of labor productivity growth in 2007 (p10 to p90)}
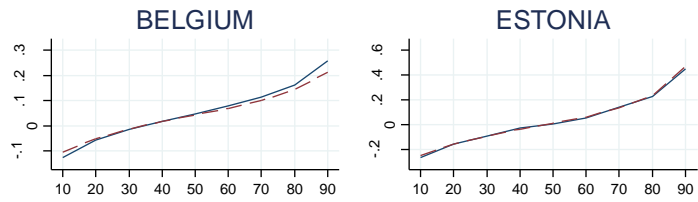

FRANCE
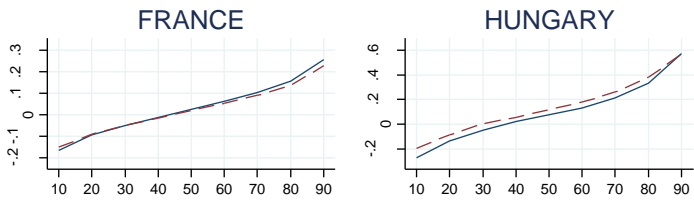

SLOVAKIA
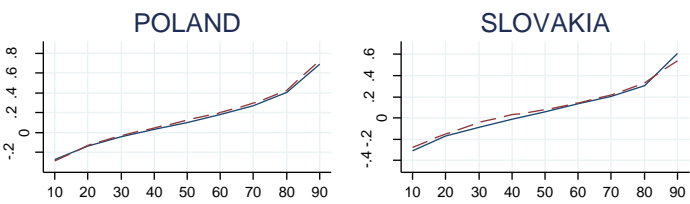

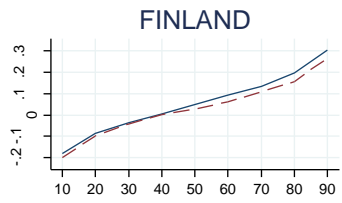

ITALY

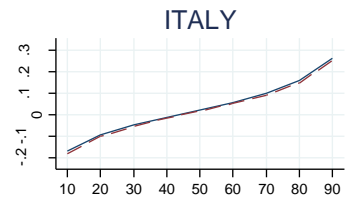

SLOVENIA

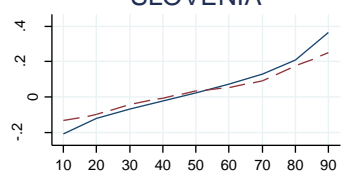

Exporters - - - - Non-exporters

Note: Graph obtained using the sample with more than 20 employees and harmonized thresholds, at country-level.

We complement this investigation by replicating these charts for the growth of firm-level labor productivity. In Figure 5.6, the growth rate of labor productivity declined sharply during the year of the trade collapse, with a rebound for most countries in the following year. As in the case of the growth of wages, however, we do not observe any clear-cut heterogeneity between exporters and non-exporters in terms of their productivity dynamics, whereas the previous section identified a higher productivity level for the population of exporters. To complete the analysis, we report in Figure 5.7 the distribution of firm-level productivity growth in 2007 for the population of exporters and non-exporters. It confirms that exporters and non-exporters do not present systematic differences in terms of their productivity dynamics. This result is robust across years and countries. In an unreported chart, we also confirm very similar dynamics of unit labor costs for exporters and non-exporters. ${ }^{24}$ Overall, while these results do not exclude the possibility that the dynamics of productivity and wages may differ for the two populations of firms in some years and for some countries, they show that such empirical pattern is not systematically verified and does not dominate, on average, in our sample. Hence, most of the heterogeneity between exporters and nonexporters relates to their levels of productivity and wages, consistently with the self-selection hypothesis.

${ }^{24}$ Note that in the whole CompNet exercise we are using industry-level deflators by country rather than firm-level prices. We are therefore not capturing the dynamics of prices, which may be heterogeneous for exporters and non-exporters. 


\subsection{PROFIT MARGINS AND THE FINANCIAL POSITION OF EXPORTERS AND NON-EXPORTERS}

We complete the descriptive statistics presented in the previous sections by an investigation about the profitability and financial position of exporters relative to non-exporters. Recent papers have been investigating the relationship between finance and exports at the firmlevel, mostly for single countries. They have identified that exporters (but also importers) tend to report a better financial health than non-exporters and are less likely to be financially constrained (Greenaway et al., 2007; Berman and Héricourt, 2010; Minetti and Zhu , 2011; Chor and Manova, 2012; Bas and Berthou, 2012). Other works have also identified profitability differences between the two categories of firms (Fryges and Wagner, 2010; Vogel and Wagner, 2010; Grazzi, 2012).

We complete this very dense literature mostly focusing on firm-level data for single countries by providing cross-country descriptive evidence about the financial position of exporters and non-exporters for European countries, using the joined distributions of trade and financial indicators into the CompNet dataset. In addition to the export status of the firm, the raw data underlying the CompNet database also cover financial data at the firm level. Based on financial data, several standard financial indicators (return on assets, leverage, debt burden, collateral etc.) are constructed for the full population of firms, but also for the populations of exporters and non-exporters in the CompNet's Trade module. ${ }^{25}$

Note that, as financial data is collected according to national accounting standards, making comparison across countries remains a difficult exercise. Therefore, we do not intend to compare the financial position of exporters across countries, but rather to compare exporters and non-exporters within each country and also over time. Figure 5.8 shows the evolution of median profit margins for exporters versus non-exporters over time for the 20E samples (calculated as price-cost margins). The results confirm that in most countries, exporters are more profitable than non-exporters. The pattern holds over time and the gap appears to be larger in small open economies, such as Estonia or Belgium.

${ }^{25}$ For details on how the financial indicators are constructed and their availability, the reader may refer to Ferrando et al. (2015) 


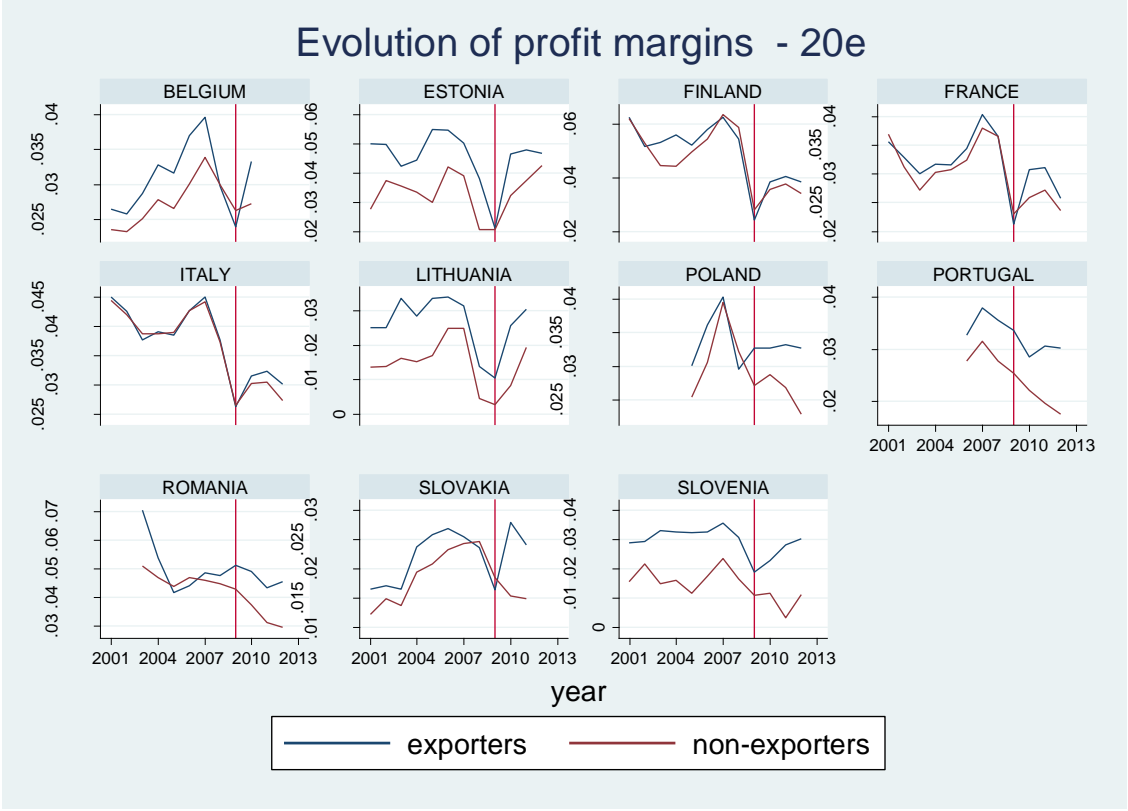

The profit margins appear to be very pro-cyclical, with a sharp decline observed in 2009 followed by a rebound the year after. This reflects the productivity pattern observed in those years for most countries, which is explained to a large extent by a drop in demand not fully compensated by a reduction of labor costs within each firm (labor hoarding). Interestingly, in most countries, the decline in profit margins in 2009 can be observed for both exporters and non-exporters, but the rebound in 2010 is often more sizeable for exporters than for nonexporters. This result may signal that exporters were able to serve demand in more dynamic markets and raising their profit margins, whereas the domestic demand in Eurozone countries especially remained weak in the following years.

We complete this evidence showing the higher profitability of exporters relative to nonexporters by reporting in Figure 5.9 the debt burden for both categories of firms, measured as the interest rate paid divided by operating profit/loss. This variable can be interpreted as an indicator of the financial fragility of firms, an increase in the ratio being associated with higher risks of default. Differences across firms, however, may also indicate heterogeneity in terms of their capacity to have access to external finance. The fact that exporters are more productive and larger than non-exporters may indeed help them to borrow more from banks, other financial intermediaries and also from suppliers through trade credit. 


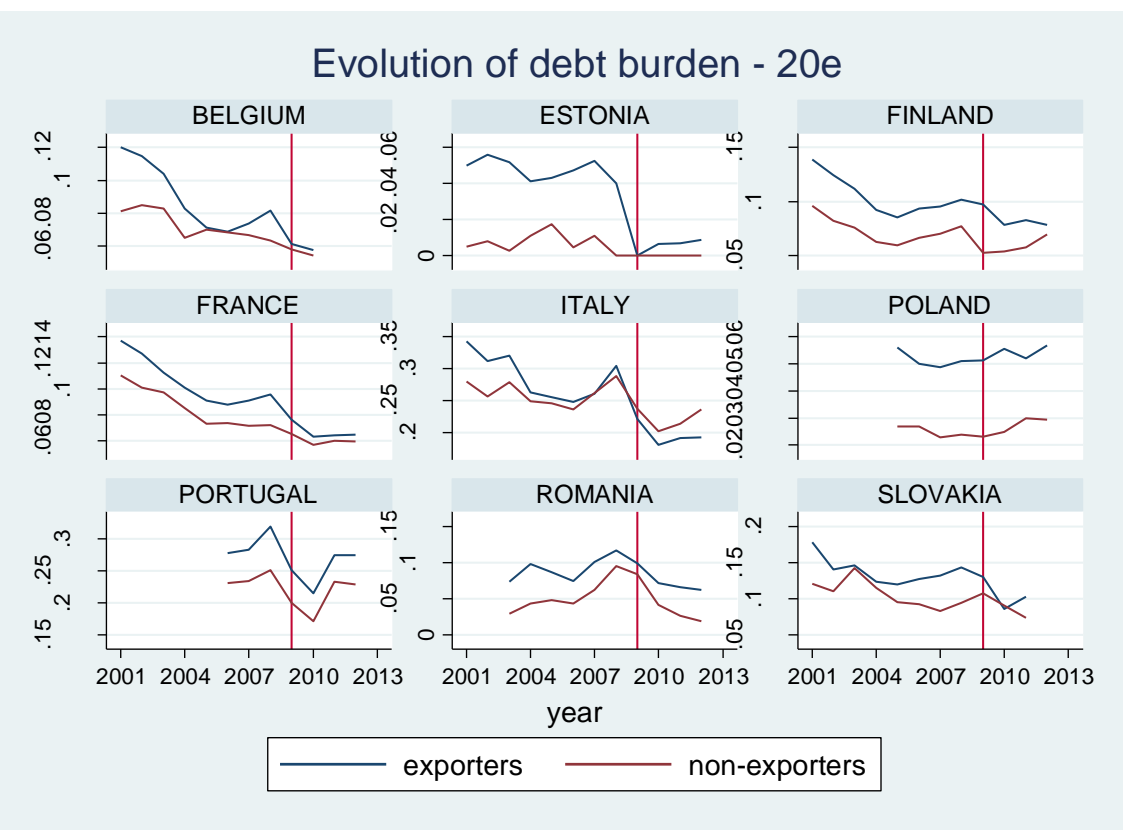

Figure 5.9 indicates that exporters tend to have a higher debt burden than non-exporters. This result is in line with the assumption retained in recent trade models (see for instance Manova, 2013) that exporting requires paying an additional fixed cost compared to selling goods in the home market, which has to be financed by financial intermediaries or suppliers through trade credit. The dynamics of the debt burden for each category of firms appears quite volatile since 2008. The decline in the debt burden observed in many countries may be related to a decline of the supply or demand of credit, to the reduction in the policy rates in Eurozone countries, or even to firm-selection during the crisis. ${ }^{26}$ We also observe in some countries such as Estonia, France or Italy that the decline in the debt burden was more sizeable for exporters with respect to non-exporters. More research will be needed in order to establish the sources of these heterogeneous dynamics for exporters relative to nonexporters.

\footnotetext{
${ }^{26}$ The role of firm-selection is unclear here, as the debt burden may increase by a composition effect if more fragile firms with less access to external finance ex-ante went bankrupt during the crisis.
} 


\section{FIRM-LEVEL PRODUCTIVITY AND THE INTENSIVE MARGIN OF EXPORTS}

\subsection{FIRM-LEVEL PRODUCTIVITY AND EXPORT INTENSITY}

This section aims at analyzing the intensive margin of exports (i.e., the amount exported per firm). While the extensive margin (e.g. firm selection) is important in explaining the crosssectional distribution of aggregate exports across destinations, adjustments along the intensive margin seems to dominate in the short run (see for example Hummels and Klenow, 2005, Amurgo-Pacheco and Pierola, 2008, Behrens et al., 2013, Bricongne et al., 2012, etc.).

Figure 6.1 - Correlation coefficients between exports' values/intensity and labor productivity (2006-2012)

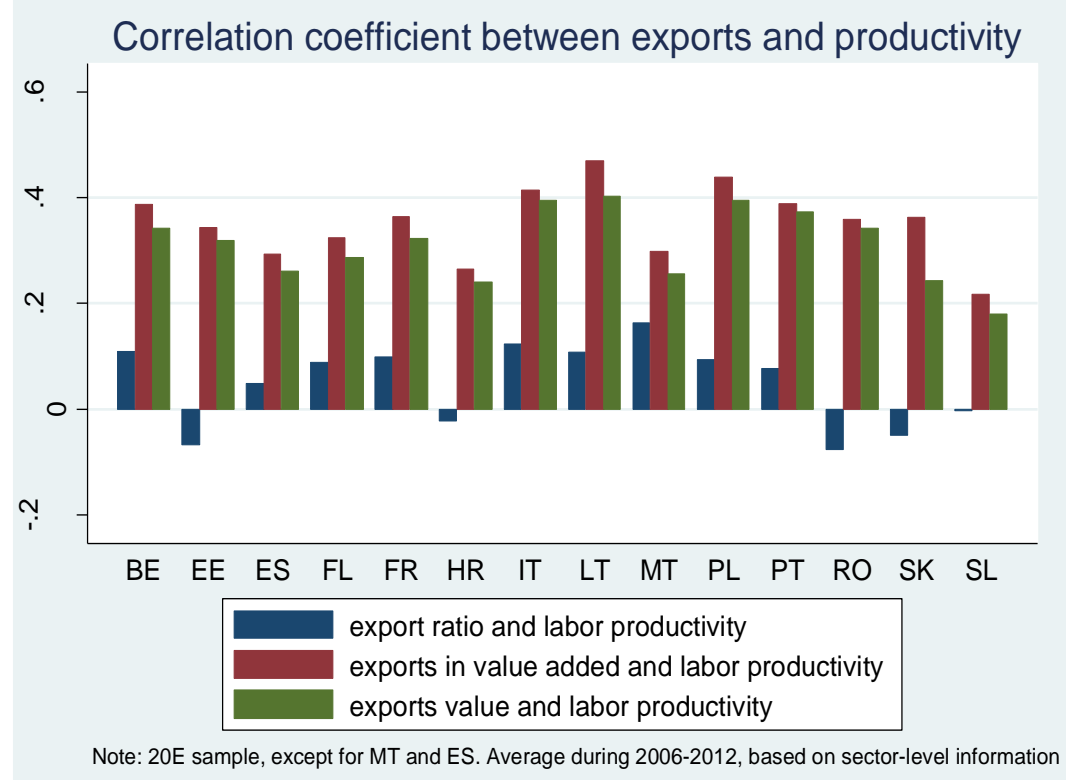

We report in Figure 6.1 the coefficient of correlation (period average) between firm-level exports and firm-level productivity. This picture is completed with the correlation of firm productivity with the exports intensity, defined as the ratio of exports over turnover. ${ }^{27}$ This correlation is on average positive and confirms previous findings in the literature. Conditional on being an exporter, more productive firms tend to export more than less productive ones.

The correlation of productivity with exports intensity is also positive on average, but less strong. This implies that an important part of the positive correlation between productivity and exports is explained by the fact that more productive firms are also larger. Still, beyond

\footnotetext{
27 The numbers reported are averages over the period 2006-2012.
} 
firm size, productivity tends to increase the firm-level exports intensity in a number of countries.

To complete this picture and take into account the possibility that the relation between productivity and firm-level export values may be non-linear, in Figure 6.2, we report the ratio of the export value of the productivity decile $\mathrm{x}$ relative to the exports value for firms with the median productivity, in each country. Firms in top productivity deciles in all countries export, on average, $66 \%$ more than the median firm in terms of productivity, while exports for firms in the lower buckets are about $40 \%$ below the values for the median class.

Figure 6.2 - Exports' value per firm (logs) relative to median labor productivity class (2006-2012)

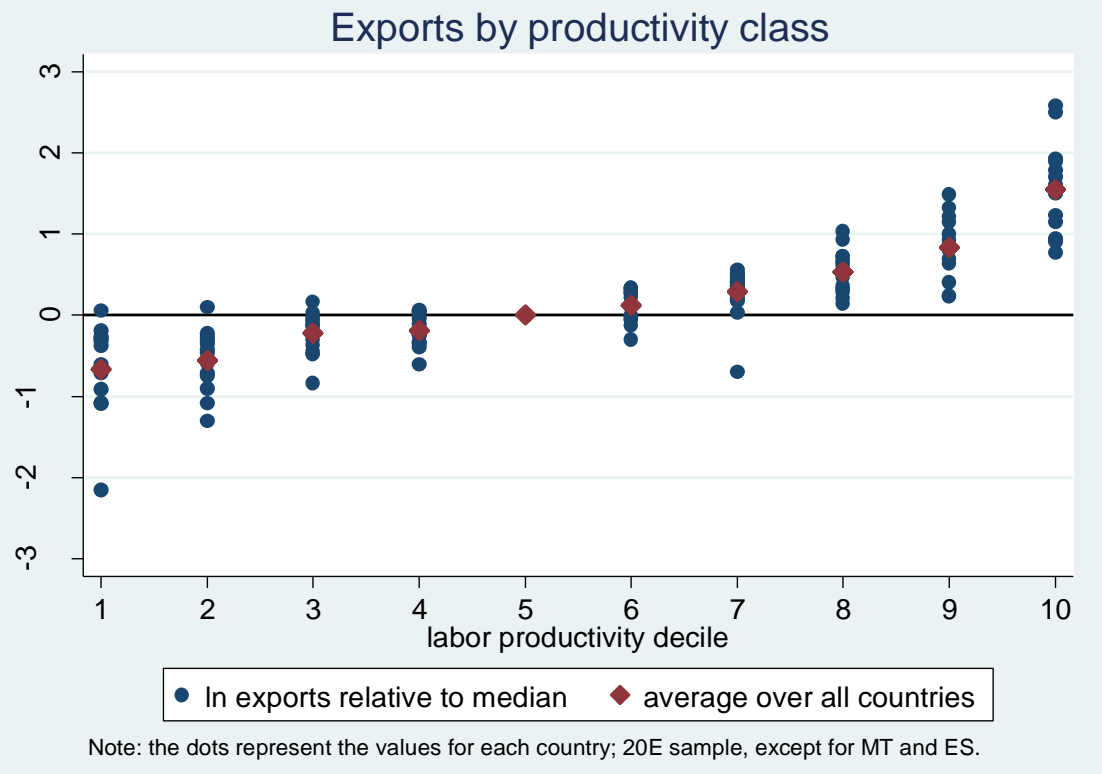

Note: chart produced using the country-level files of the CompNet's Trade module, adjusted for reporting thresholds, 20E sample.

This leads to a concentration of exports in the top labor productivity deciles. On average across sectors and countries, results reported in Figure 6.3 show that most productive firms in the $10^{\text {th }}$ decile of the productivity distribution account, on average over the 2006-2012 period, more than a quarter of total exports, while the shares of firms displaying a below median productivity averaged at under $5 \%$. This result completes evidence discussed in section 4.3 where we identified that top exporters in each country make the bulk of aggregate exports. The numbers reported in Figure 6.3 confirm that these firms are much more productive than any other firm in each sector and country, which may result from their better ability to profitably export a wide variety of goods to a large number of destinations. More research is certainly needed to identify the sources of their success (e.g. the role of research and development, managerial skills, or networks aspects of the firm's activity such as belonging to a business group or more generally participating to global value chains). Also, as already discussed, a consequence of this very high concentration of exports among a small number of large companies is that productivity shocks affecting these firms must have a very strong impact on aggregate export performance. 


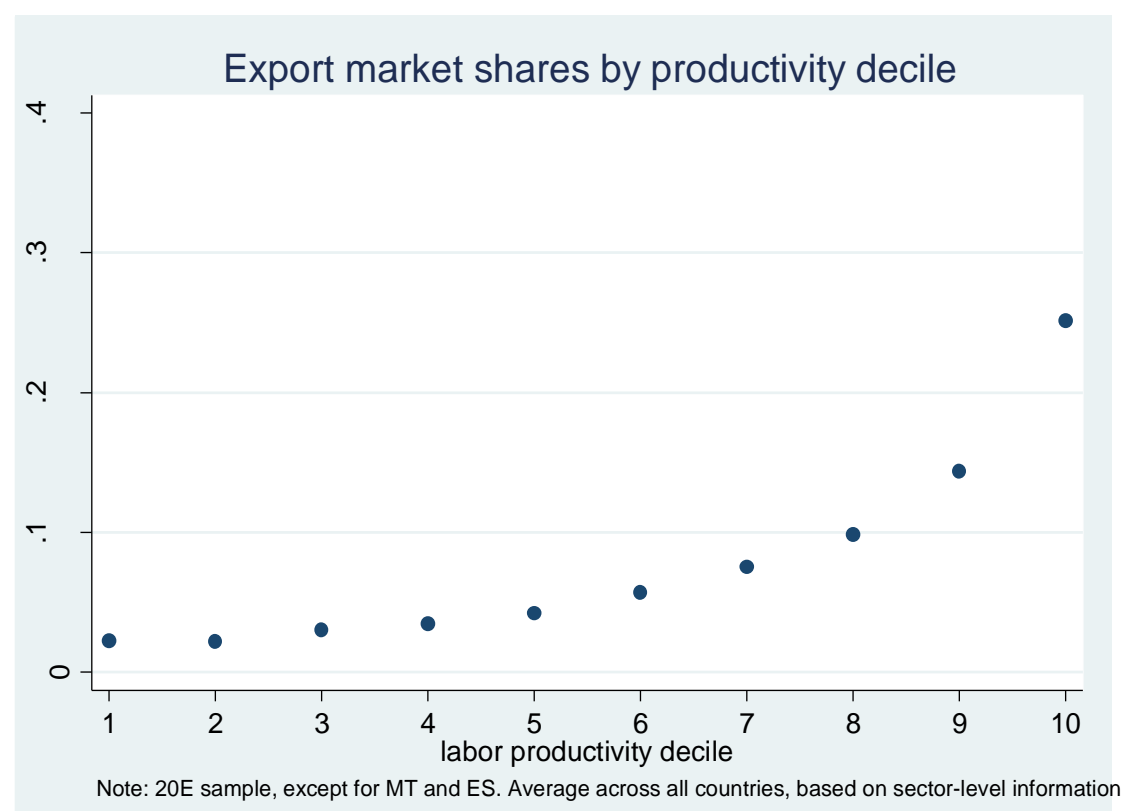

\subsection{EXPORT DYNAMICS AND FIRM PRODUCTIVITY}

Accounting for firm heterogeneity in terms of productivity is key to understand export dynamics. More productive firms are not only more likely to become exporters, but may also behave differently in adjusting their intensive margins in response to other macroeconomic shocks. In this section, we look at how export performance differed during the most recent economic cycles along the productivity distribution of firms.

Comparing exporting firms below and above the median productivity (TFP), we find that more productive firms are more likely to exhibit a higher increase or a lower decline in their average export growth rates. This result is summarized in Figure 6.4, which tracks export growth of these two groups of firms from 2006 to 2012. The average growth rates are calculated, separately, for each country and over 3 different periods, that is a pre-crisis phase (2006-2007), the post-Lehman phase (2008-2009) and the latest period (2010-2012). For all countries and sub-periods, results show that more productive exporters have, on average, higher export growth. In 2008-2009, when exports declined sharply, more productive exporters experienced a smaller drop in export growth. In addition, our results imply that this advantage of the more productive firms was carried over to the recovery period, to 2010-12. On average, the difference in the growth rate of low and high productivity firm is similar to the difference before the crisis. 


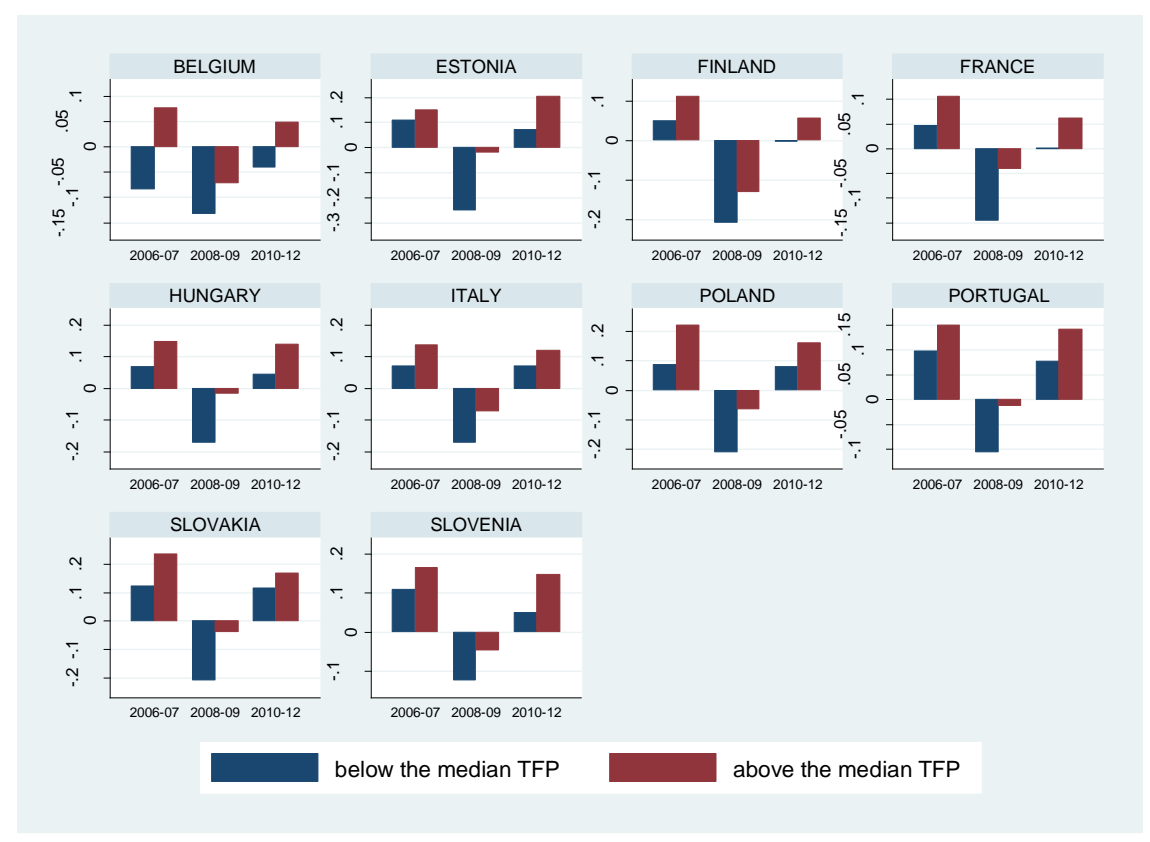

It is worthwhile noting that this result does not account for country-specific effects or sectorlevel differences across countries. In addition, systematic difference in growth rates across small and large scale exporters may also drive the above results if productivity and the level of export sales are correlated. Using the sector-level version of the data, we compare the export growth of firms by running OLS regression. We control for country-, sector- and timespecific differences that might exist between high and low productivity firms. The key insights remain unchanged as illustrated by Figure 6.5 , which indicates that, on average, there is about a 20 percentage point difference in the export growth rate of the least and most productive exporters even after controlling for sector composition, year and country effects. 


\section{Figure 6.5 - Average export growth of firms by TFP deciles}

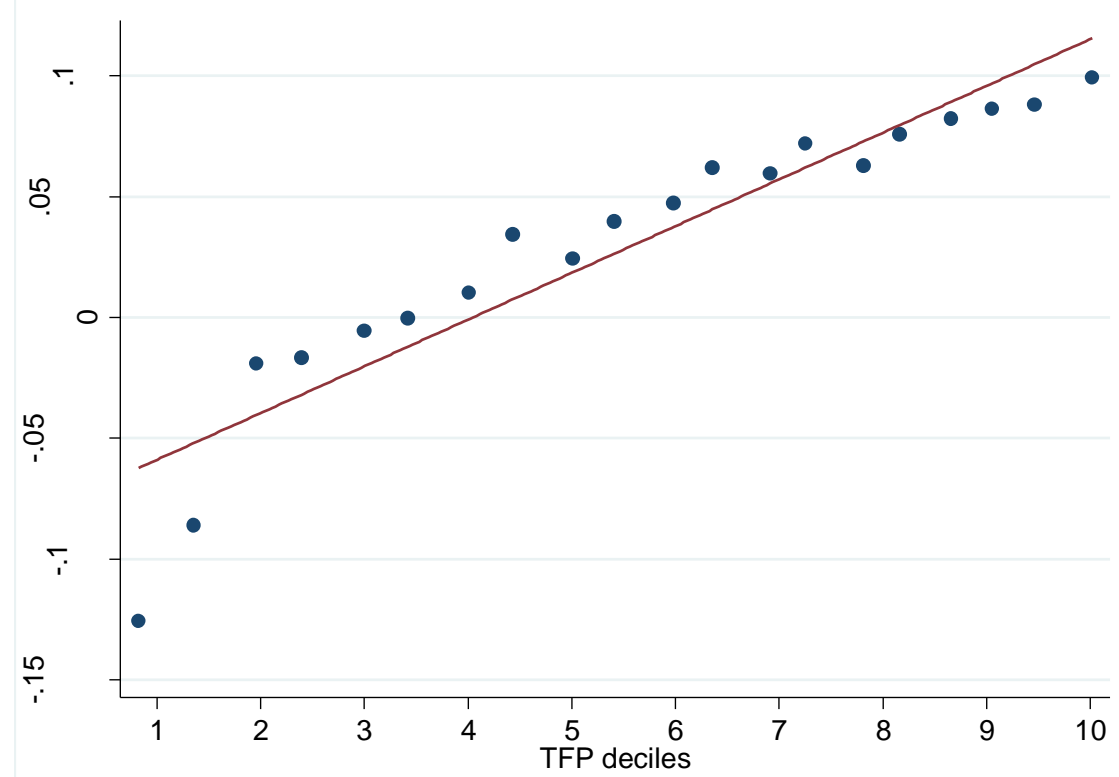

Note: Firms' export growth averaged over the deciles of TFP for all countries using the CompNet 20+ database. The regression line results from controlling for country and sector fixed effects and lagged export value. The slope of the regression line expresses the average growth difference by deciles assuming the same difference between each decile due to linearity.

\subsection{EXPORT DYNAMICS AND FIRM PRODUCTIVITY DURING THE CRISIS}

We now move a step forward and ask whether the micro evidence on the relationship between export growth and productivity can provide some new light on the macro side. The Eurozone crisis has been characterized by significant cross-country heterogeneity in terms of current account dynamics, with ex-ante deficit countries facing a sharp current account adjustment, whereas little reverse adjustment was observed among surplus countries. In this exercise, we make use of our database in order to identify the contribution of low versus high productive firms (within the population of exporters) to this process of current account adjustment. In Figure 6.6, we plot the current account adjustment recorded by CompNet countries between 2008 and 2012 (as a percentage of GDP) against export growth in 201112 for two groups of firms: high (above median) and low (below median) productivity firms.

The data shows quite neatly a statistically significant and positive correlation between current account adjustments and export growth only among the most productive firms (right panel). This is to say that, from the export side, the reduction of external imbalances within Europe is essentially driven by the exports growth of the most productive firms in ex ante 
deficit countries. ${ }^{28}$ The less productive firms, on the contrary, were not able to grow in the exports market. This evidence is consistent with preliminary results in the trade literature (e.g. Berthou and Vicard, 2013 or Eaton et al., 2007) showing that only a small number of very high productive firms are able to operate durably on global markets, whereas less productive firms have a less stable participation and are more exposed to domestic shocks.

Even if a much more careful analysis is required to derive robust implications for policy, this simple graph proves that insights from micro data can provide a new perspective on a macro variable, like the current account balance.

\section{Figure 6.6 - Current account adjustment and export growth by productivity level}
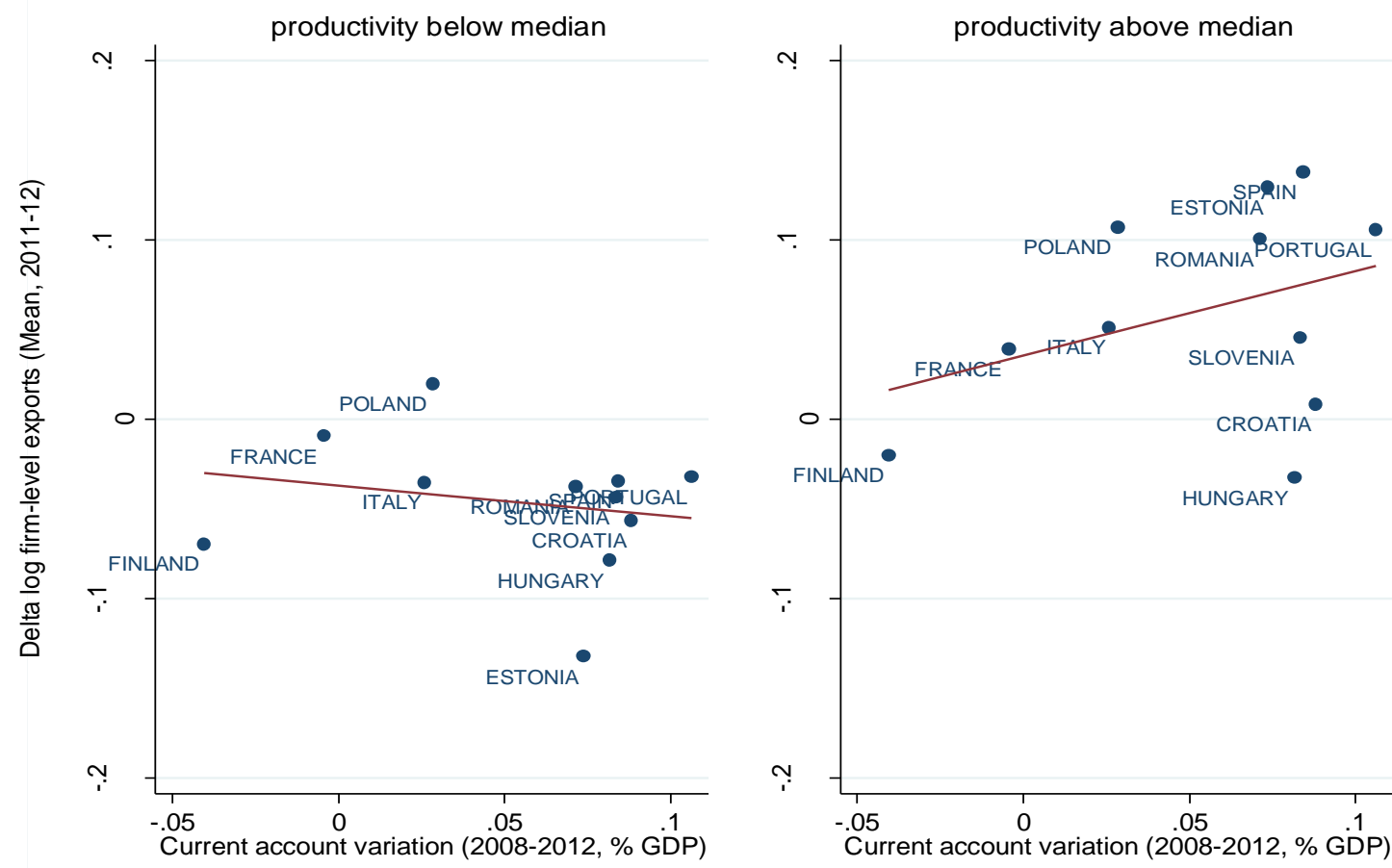
version is only collecting the import status of firms when available, but not the import value. 


\section{CONCLUSION}

In this paper, we provided a detailed analysis regarding the activity of European exporting firms. This cross-country study is based on the CompNet's Trade module, which reports for 15 countries so far information about the joint distributions of productivity and trade at the firm-level by sector. Unlike most studies published so far reporting descriptive evidence for the populations of exporters and non-exporters, the indicators were obtained by running for several countries a single program. This ensures that differences across countries are not driven by the use of different empirical methodologies. ${ }^{29}$

We reported a series of descriptive statistics with the objective of confirming stable empirical relations for a large set of countries. We first identified that in all countries aggregate exports are highly concentrated among a very small set of firms. We then confirmed the key role played by productivity in determining firm-level export participation and survival. Finally, we provided evidence that productivity is a strong determinant of export performance of firms. Top productive firms are indeed the ones that concentrate the bulk of aggregate exports in each country and industry. On top of this, firm-level productivity has also a significant influence on firm-level exports growth. We showed in particular that during the crisis, the export growth of the most productive firms facilitated the current account adjustment of European "stressed" countries, while the exports of the low productive firms remained stagnant.

While the aim of this paper was to provide a series of stylized facts using the CompNet's Trade module, which, we believe, is a useful material for policy analysis focusing on the evaluation of countries' competitiveness, other research projects, initiated within the CompNet network, have already started using this data. For instance, Berthou, Demian and Dhyne investigate the impact of real exchange rates movements on firm-level exports, and provide new cross-country evidence about the heterogeneous response of firms based on their size or their productivity. The different response of low versus high productive firms contributes to the explanation of the so-called exchange-rate disconnect puzzle. In a different project, Demian and Di Mauro study the link between exchange rate movements and aggregate exports by country, and identify the role played by the dispersion of productivity within sectors. Barba Navaretti et al. estimate a general gravity equation to test whether aggregate exports are solely determined by average productivity, as predicted in standard trade models with heterogeneous firms à la Melitz (2003), or also by higher-order moments of the productivity distribution as the evidence on top exporters herein shown would suggest. Finally, Berthou, Manova and Sandoz investigate the effects of trade (export opportunities, import of inputs and import competition) on misallocation and aggregate productivity.

These research projects will provide new insights about the role played by micro-level heterogeneity for a better and more informed evaluation of competitiveness and growth in Europe.

As noted in the introduction, cross-country heterogeneity in terms of the underlying samples or accounting rules remain, and continue to affect the indicators published in the CompNet's trade module. Future users of this data should therefore carefully interpret cross-country comparisons. 


\section{BIBLIOGRAPHY}

Amiti, Mary, Oleg Itskhoki and Jozef Konings. 2014. "Importers, Exporters, and Exchange Rate Disconnect." The American Economic Review, 104(7), 1942-78.

Amurgo-Pacheco, A. and Martha D. Pierola. 2008. "Patterns of Export Diversification in Developing Countries: Intensive and Extensive Margins." World Bank Policy Research Working Paper, (4473).

Bas, Maria and Berthou, Antoine, 2012."The Decision to Import Capital Goods in India: Firms' Financial Factors Matter," World Bank Economic Review, World Bank Group, vol. 26(3), pages 486-513.

Behrens, Kristian; Gregory Corcos and Giordano Mion. 2013. "Trade Crisis ? What Trade Crisis ?" The Review of Economics and Statistics, 95(2), 702-09.

Békés, Gábor, Balázs, Muraközy and Péter Harasztosi. 2011. "Firms and products in international trade: Evidence from Hungary." Economic Systems, 35(1), 4-24.

Berman, Nicolas and Héricourt, Jérôme, 2010."Financial factors and the margins of trade: Evidence from cross-country firm-level data," Journal of Development Economics, Elsevier, vol. 93(2), pages 206-217, November.

Bernard, Andrew B. and Bradford Jensen, J., 1999. "Exceptional exporter performance: cause, effect, or both?," Journal of International Economics, Elsevier, vol. 47(1), pages 1-25, February.

Berthou, Antoine and Vincent Vicard. 2013. "Firms' Export Dynamics: Experience Vs Size." ECB Working Paper, (1616).

Bricongne, Jean-Charles; Lionel Fontagné; Guillaume Gaulier; Daria Taglioni and Vincent Vicard. 2012. "Firms and the Global Crisis: French Exports in the Turmoil." Journal of International Economics, 87(1), 134-46.

Cebeci, Tolga; Ana M. Fernandes; Caroline Freund and Martha D. Pierola. 2012. "Exporter Dynamics Database." World Bank Policy Research Working Paper, (WPS 6229).

Chaney, Thomas. 2008. "Distorded Gravity: The Intensive and Extensive Margins of International Trade." American Economic Review, 98(4), 1707-21.

Chor, Davin and Kalina Manova. 2012. "Off the Cliff and Back? Credit Conditions and International Trade During the Global Financial Crisis." Journal of International Economics, 87(1), 117-33.

De Backer, Koen and Sébastien Miroudot. 2014. "Mapping Global Value Chain." ECB Working Paper, (1677).

De Loecker, Jan. 2007. "Do Exports Generate Higher Productivity ? Evidence from Slovenia." Journal of International Economics, 73, 69-98.

Di Mauro, Filippo, and Pappada, Francesco. 2014. "Euro area external imbalances and the burden of adjustment." Journal of International Money and Finance.

Eaton, Jonathan; Marcela Eslava; Maurice Kugler and James Tybout. 2007. "Export Dynamics in Colombia: Firm-Level Evidence." NBER Working paper, (13531).

Ferrando, A., C. Altomonte, S. Blank, P. Meinen, M. Iudice, M.-H. Felt, K. Neugebauer, I. Siedschlag. 2015. "Assessing the financial and financing conditions of firms in Europe: the financial module in CompNet." ECB Working Paper no 1836.

Freund, Caroline and Martha D. Pierola. 2010. "Export Entrepreneurs: Evidence from Peru." World Bank Policy Research Working Paper, (5407).

Fryges, Helmut and Joachim Wagner. 2010. "Exports and Profitability: First Evidence for German Manufacturing Firms." The World Economy, 33(3), 399-423. 
Gabaix, Xavier. 2011. "The Granular Origins of Aggregate Fluctuations." Econometrica, 79, 733-72.

Gaulier, Guillaume, and Vicard, Vincent. 2013. "The signatures of euro area imbalances: export performance and the composition of ULC growth." CompNet Policy Brief 02/2013.

Grazzi, Marco. 2012. "Export and Firm Performance: Evidence on Productivity and Profitability of Italian Companies." Journal of Industry, Competition and Trade, 12(4), 413-44.

Greenaway, David; Alessandra Guariglia and Richard Kneller. 2007. "Financial Factors and Exporting Decisions." Journal of International Economics, 73(2), 377-95.

Hummels, David and Peter Klenow. 2005. "The Variety and Quality of a Nation's Exports." American Economic Review, 95(3), 704-23.

ISGEP. 2008. "Understanding Cross-Country Differences in Exporter Premia: Comparable Evidence for 14 Countries." Review of World Economics, 144(4), 596-635.

Lopez-Garcia, Paloma; Filippo di Mauro; Nicola Benatti; Chiara Angeloni; Carlo Altomonte; Matteo Bugamelli; Giorgio Barba Navaretti; Emanuele Forlani; Stefania Rossetti; Davide Zurlo; Antoine Berthou; Charlotte Sandoz-Dit-Bragard; Luca David Opromolla; Ana Cristina Soares; Bogdan Chiriacescu; Ana-Maria Cazacu; Tibor Lalinsky; Emmanuel Dhyne; Elena Biewen; Sven Blank; Philipp Meinen; Jan Hagemejer; Patry Tello; Urska Cede; Kamil Galuscak; Jaanika Meriküll and Peter Harasztosi. 2014. "Micro-Based Evidence of Eu Competitiveness : The CompNet Database." ECB Working Paper.

Lopez-Garcia, Paloma; Filippo di Mauro and the CompNet Task force. 2015. "Assessing European competitiveness: the new CompNet microbased database." ECB Working Paper no 1764.

Manova, Kalina 2013."Credit Constraints, Heterogeneous Firms, and International Trade," Review of Economic Studies, Oxford University Press, vol. 80(2), pages 711-744.

Masso, Jaan and Priit Vahter. 2015. "Exporting and productivity: the effects of multi-product and multi-market export entry." Scottish Journal of Political Economy.

Melitz, Marc J. 2003. "The Impact of Trade on Intra-Industry Reallocations and Aggregate Industry Productivity." Econometrica, 71(6), 1695-725.

Mion, Giordano and Luca David Opromolla. 2014. "Managers' mobility, trade performance and wages." Journal of International Economics, 94(1), 85-101.

Minetti, Raoul and Susan Chu Zhu. 2011. "Credit Constraints and Firm Export: Microeconomic Evidence from Italy." Journal of International Economics, 83(2), 109-25.

Ottaviano, Gianmarco and Thierry Mayer. 2007. "The Happy Few: The Internationalisation of European Firms," Bruegel Blueprints. Brussels: Bruegel.

Secchi, Angelo, Federico Tamagni and Chiara Tomasil. 2014. "Financial constraints and firm exports: accounting for heterogeneity, self-selection and endogeneity," Sant'Anna School of Advanced Studies LEM Working Paper2014/16.

Vogel, Alexander and Joachim Wagner. 2010. "Higher Productivity in Importing German Manufacturing Firms: Self-Selection, Learning from Importing, or Both ?" Review of World Economics, 145(4), 641-65.

Wagner, Joachim. 2012. "International Trade and Firm Performance: A Survey of Empirical Studies since 2006." Review of World Economics, 148, 235-2467.

\section{ONGOING RESEARCH USING DATA FROM TRADE MODULE}

Barba Navaretti, Giorgio, Matteo Bugamelli, Emanuel Forlani and Gianmarco Ottaviano. "Firms and aggregate trade performance". 
Berthou, Antoine, Demian, Vlad and Dhyne, Emmanuel. "The heterogeneous impact of exchange rates movements on European exporters".

Berthou, Antoine, Manova, Kalina and Sandoz, Charlotte 'International trade, productivity and misallocation".

Demian, Vlad and di Mauro, Filippo. "Exchange rates movements, aggregate exports, and productivity dispersion within sectors".

\section{Appendix A. FIRM-Level trade DATASETS}

\section{BY COUNTRY}

As accessing to firm level information for a large set of countries is either too costly or almost impossible because of the legal confidentiality constraints associated to firm level data, the construction of such a joined database provides an easy access to a unique set of indicators that can only be computed on the basis of firm level information. The ESCB CompNet members initially developed a common database providing moments of firm level observations/ estimations of total factor productivity (hereafter TFP), labor productivity or unit labor costs, measured at the NACE Rev. 2 two digit level or at more aggregated level for a set of EU countries from mid 1990s to early $2010 \mathrm{ss}^{30}$ In addition to this first set of results, it was also decided to complement the dataset with additional modules that would provide similar information for sub-set of the population of firms. Among those modules, the Trade module has been developed to document the firm-level performance on export markets and the distribution of firm characteristics for the population of exporters versus of nonexporters. We provide below some details regarding the underlying firm-level datasets that were used in each country to run the CompNet's Trade module.

Belgium. Firm level exports and imports data are provided by the Belgian customs for extra EU trade and directly by exporting/importing firms for the intra EU trade (intra-stat declarations) to the National Bank of Belgium statistical department in order to establish the official trade statistics for Belgium. Under specific agreements, NBB researchers involved in the present paper have been granted access to the individual firm declarations. The raw data detail for each firm (identified by its VAT number) the value in euros and the quantity (in $\mathrm{kg}$ or in an ad-hoc unit) exported/imported each year by country of destination/origin and 8digits Combined Nomenclature (CN8) product categories. Specific reporting thresholds for intra-EU trade apply. These reporting thresholds are time-varying and are reported in Table 1 of the paper. After aggregating all exports / imports at the firm level, the total exports / imports values have been merged with the Belgian balance sheet dataset described in LopezGarcia et al. (2015) using the VAT number of the firms.

Croatia. Firm-level exports and imports cover both goods and services. The data is provided in the Annual Financial Statements Registry issued by the Financial Agency (Financijska agencija, Fina) to which legal entities liable to corporate income tax report directly. The 
Registry contains information on annual basis of different balance sheet categories and international trade. The international trade data includes firm-level revenues from sales abroad and imports and does not include any threshold.

Estonia. Firm-level exports and imports data are provided by Statistics Estonia for the researchers in the Bank of Estonia. The same dataset is used for the compilation and publication of Foreign Trade Statistics of goods. Extrastat data is collected by the Estonian Tax and Customs Board originally for the customs purposes. Extrastat data contain practically the whole information on the trade with non-EU countries (so called third countries). There are no data losses caused by non-response or by other issues. Intrastat data is being collected for the statistical purposes. Intrastat data are based on statistical declarations and companies with lower foreign trade turnover are not obliged to submit data. The reporting threshold is time-varying aiming to cover the same share of exporters each year. Additionally there are other data losses caused by non-response or late response. Missing data are replaced with estimations and estimated figures are revised upon receiving additional information. According to confidentiality agreement the data can be processed only in the computers of Statistics Estonia, firm-level trade data is merged with Business Register in the computer of Statistics Estonia using Statistics Estonia own firm IDs.

Finland. Foreign Trade Statistics data on exports and imports of goods are provided by the Finnish Customs. Reporting thresholds for intra-EU and extra-EU trade change over time and are reported in Table 1 of the paper. Trade values are summed for each individual firm and year by Statistics Finland due to confidentiality restrictions. Using unique firm identifiers this data is then linked with the firm-level data from the Structural Business Statistics (SBS) of Statistics Finland. The SBS data covers basically the universe of firms in Finland. The selfemployed are excluded from the database.

France. Firm-level exports and imports data are provided by the French Customs under specified agreement with Banque de France researchers involved in the present paper. The raw data detail for each individual firm (defined with a unique identifier for each legal entity) the value in euros and quantity exported each year by destination country and 8-digits Combined Nomenclature (CN8) product category. Reporting thresholds for intra-EU trade and extra-EU trade change over time and are reported in Table 1 of the paper. Trade values are summed for each individual firm and year; the final dataset is therefore firm-year specific. This data is then merged with the balance-sheet data provised by the Banque de France (Fiben) using the unique firm-identifier in the two datasets (SIREN). The final dataset is composed of a maximum of 14,857 exporters (Table 3) over the period 1995-2012.

Hungary. Firm level exports and imports are provided by the Central Statistical Office (CSO). The sources of the data are the customs declarations and intra-stat surveys with thresholds reported in Table 1 of the paper. The trade values for firms and year are merged into the balance sheet data also provided by the CSO. The balance sheet data is compiled of corporate income tax declarations collected by the tax authority, and tax numbers provide unique firm identifiers.

Italy. The database contains about 4.5 million observations from 2001 to 2012, of which 426 thousand in the last year 2012. It is a multi-source database and the sources are the following: (1) Statistical Business Register (SBR: Asia); (2) Custom data; (3) Balance sheet database; (4) Large enterprise survey (SCI). The Statistical Business Register (Asia) has 
been integrated with historical changes in the business unit and company group (transformation events) in order to reconstruct a statistical unit connected to more legal units. Moreover the inclusion of corporate events had permitted to reduce mismatches when multiple sources are integrated. The dataset represents the $85 \%$ of the reference population in 2012 and the $90 \%$ of total employment. The reference population is represented by Limited Liability Companies with employees, that are 501,494 firms in 2012, of which 110,749 operating in manufacturing activities. In terms of foreign trade it covers the $91 \%$ of the Italian manufacturing exports.

Lithuania. Firm level data on exports and imports is provided by Statistics Lithuania. The sources of the data are the customs declarations and intrastat surveys with specific thresholds. The trade data for firms and years is merged with the Structural Business Data (data on balance sheet items, profit/loss statement items, employment, etc.), which is provided by Statistics Lithuania. The Structural Business Data is compiled by Statistics Lithuania employing a number of statistical data and administrative data sources.

Malta. The data are provided by the National Statistics Office. The sources of the data are the customs declarations and intra-stat surveys with thresholds of EUR700.

Poland. Firm-level data are provided by the Central Statistical Office (CSO). The source of the data is the balance sheet and financial statements forms F-01 and F-02 collected from all firms with over 9 employees every half-year (F-01) and annually (F-02). The dataset covers non-financial corporations. The data includes export revenues and selected firmcharacteristics such as the form of ownership and the level of employment. The data are anonymized by the CSO but the NACE sectoral identifiers are available.

Portugal. Firm-level data is collected under "Informação Empresarial Simplificada" (IES) since 2007 (data for 2006) by the Ministry of Justice, the Ministry of Finance and Public Administration, "Instituto Nacional de Estatística (INE)" and "Banco de Portugal (Bdp)". This database provides very detailed information on items of the balance sheet and income statements for virtually the universe of non-financial firms on a yearly basis including information in international trade. Exports and imports do not include any threshold.

Romania. Firm-level exports and imports data are provided by National Institute of Statistics. No threshold is used. The data is merged with the balance-sheet and profit and loss account data provided by Ministry of Public Finance based on unique firm-identifier.

Slovakia. Firm-level exports cover both goods and services. They are provided by the Statistical Office of the Slovak Republic together with other balance sheet indicators under an exclusive agreement with the National Bank of Slovakia. Firm level imports originate from Slovak customs. They are also provided by the Statistical Office of the Slovak Republic under an exclusive agreement with the National Bank of Slovakia. Import data is merged with the balance-sheet data using a unique firm-identifier. There are no thresholds for exports and intra-EU thresholds apply for imports (see Table 1 for more details).

Slovenia: The Balance sheet data corresponds to the total export value of goods and services. It is provided by the Agency of the Republic of Slovenia for Public Legal Records and Related Services (AJPES), to which firms report directly, by legal obligation. The custom data, on the other hand, measures the value of the exported goods. Since 2004, the custom 
data has been collected via Intrastat and Extrastat systems; before that year, it had been based entirely on customs declarations. The custom database is administered by the Statistical Office of the Republic of Slovenia (SORS) and collected by the Financial Administration of the Republic of Slovenia.

Spain. The Balance of payments Statistics (BoP) is used to identify whether a Spanish firm has exported goods between 1995 and 2011. There is a simplification reporting threshold, below which any exporting firms do not have to report about the nature of the external transaction. This reporting threshold has change over time: $3.000 €$ from 1995 to 2000; $12.500 €$ from 2001 to 2007; and, finally, $50.000 €$ from 2008 onwards. Any increase in the threshold automatically reduces the sample of exporting firms and introduces a break in the time series. In Spain, this break was relevant in 2008, when there was a significant decrease in the number of goods exporting firms that had the obligation to report to the Banco de España to compile the BoP. The BoP data are combined with the Central Balance Sheet Data and Business Registers to obtain firm level information. 


\section{Appendix B. CONTRIBUtion OF EXPORTERS BY SECTORS}




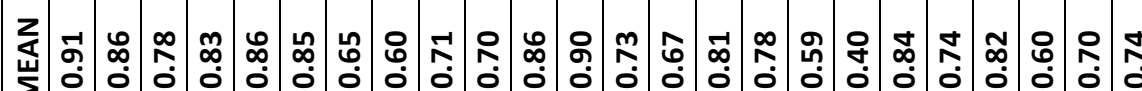

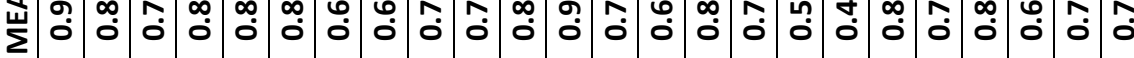

* $\cong \hat{m}$ 守

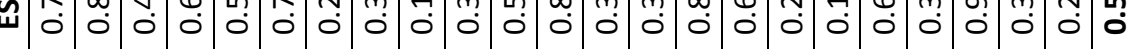

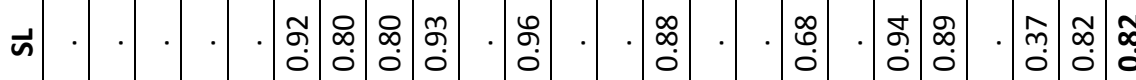

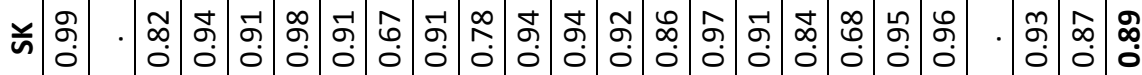

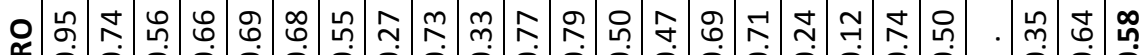

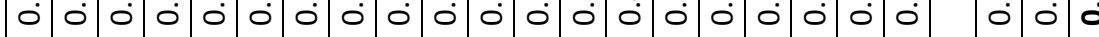
เ

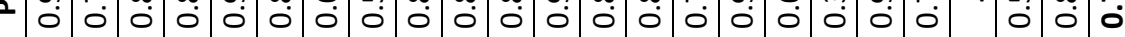

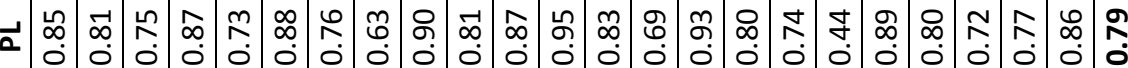

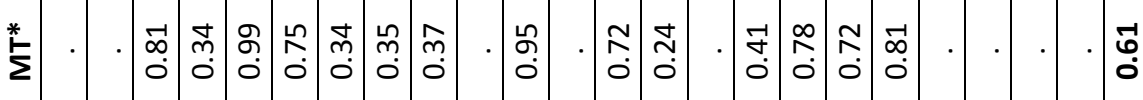

士

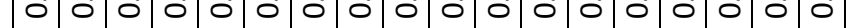

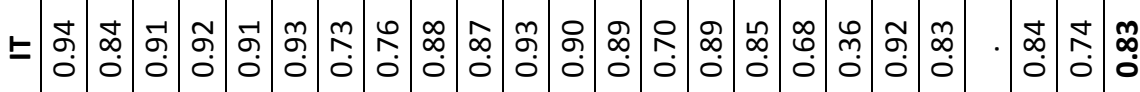

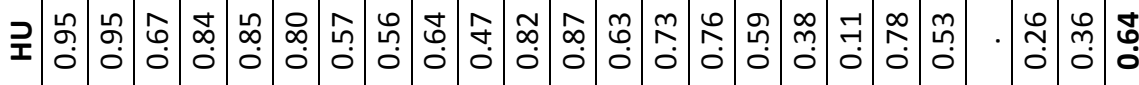

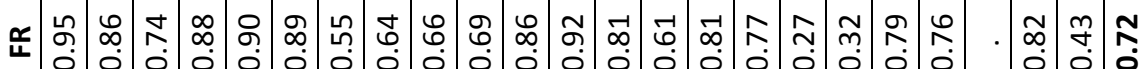
ч

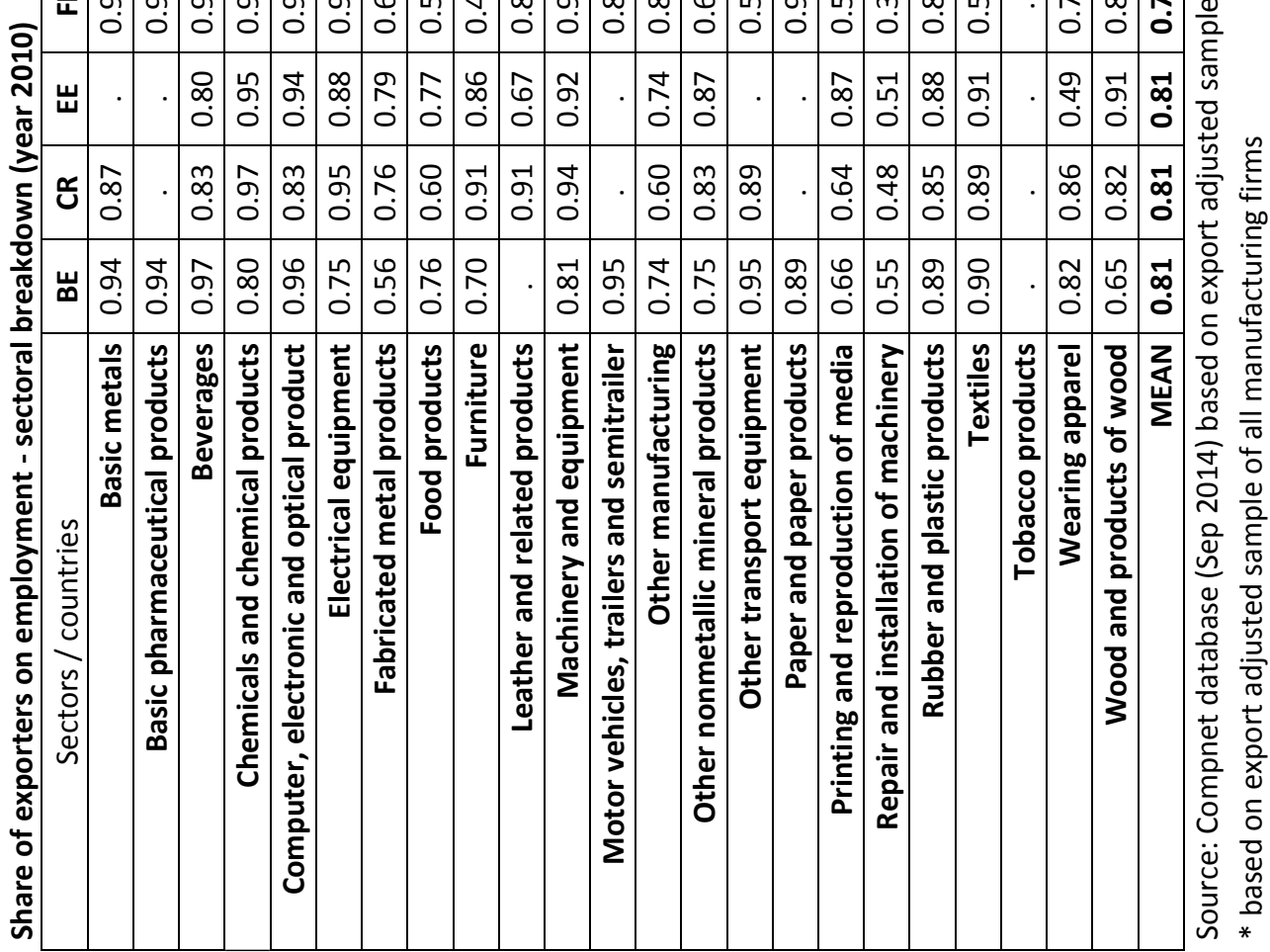




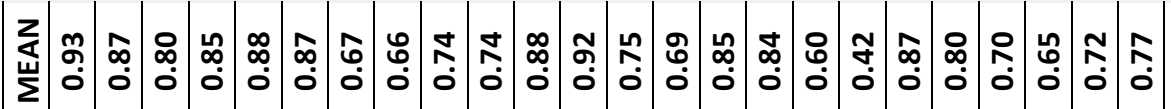

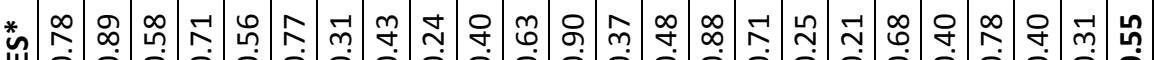

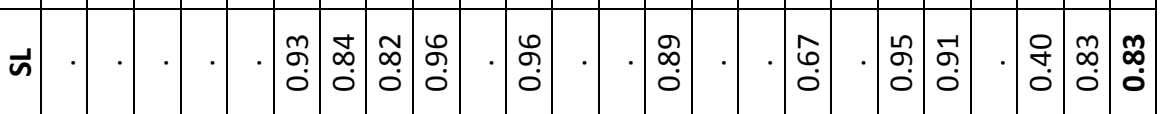

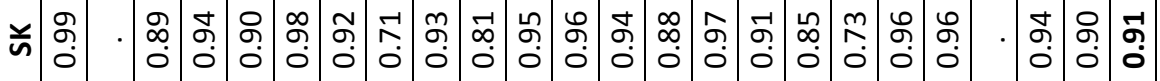

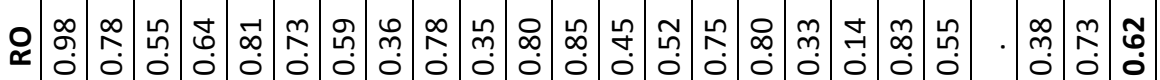

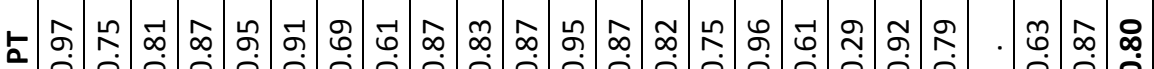

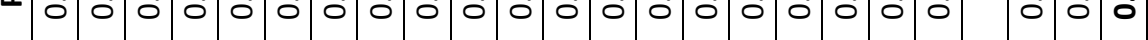

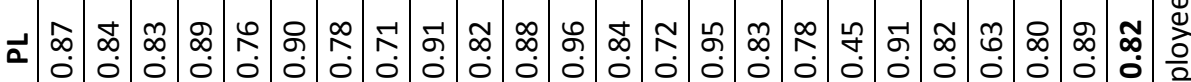

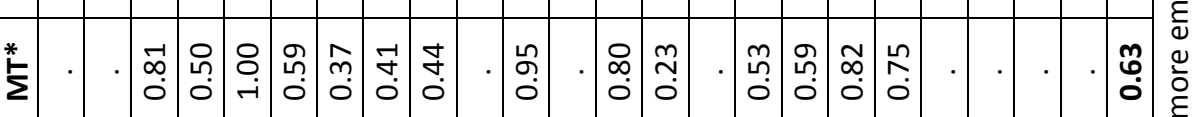

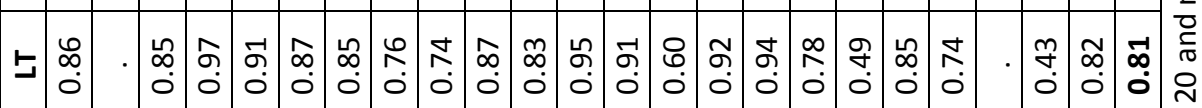

上 ஸุ

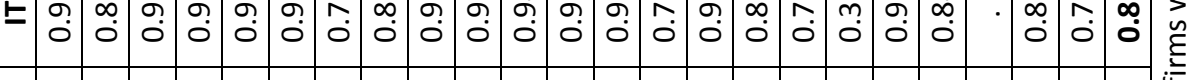

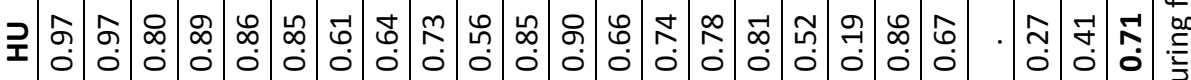

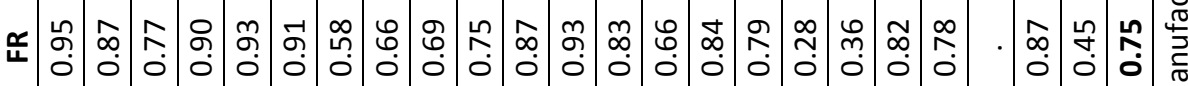

б च

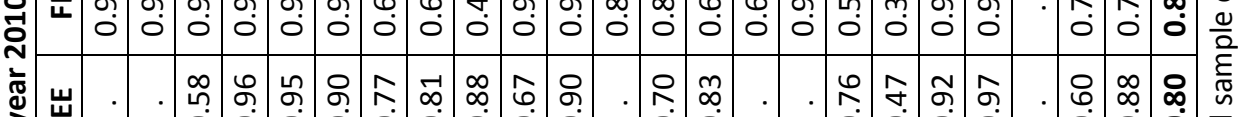

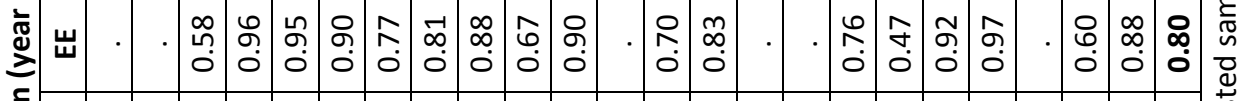

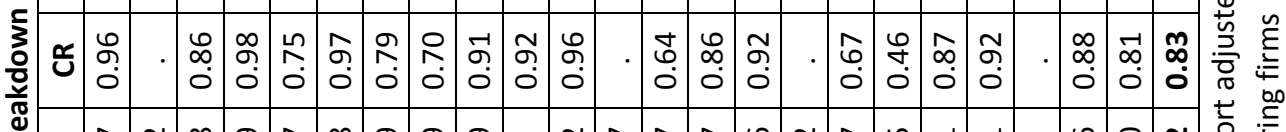

山

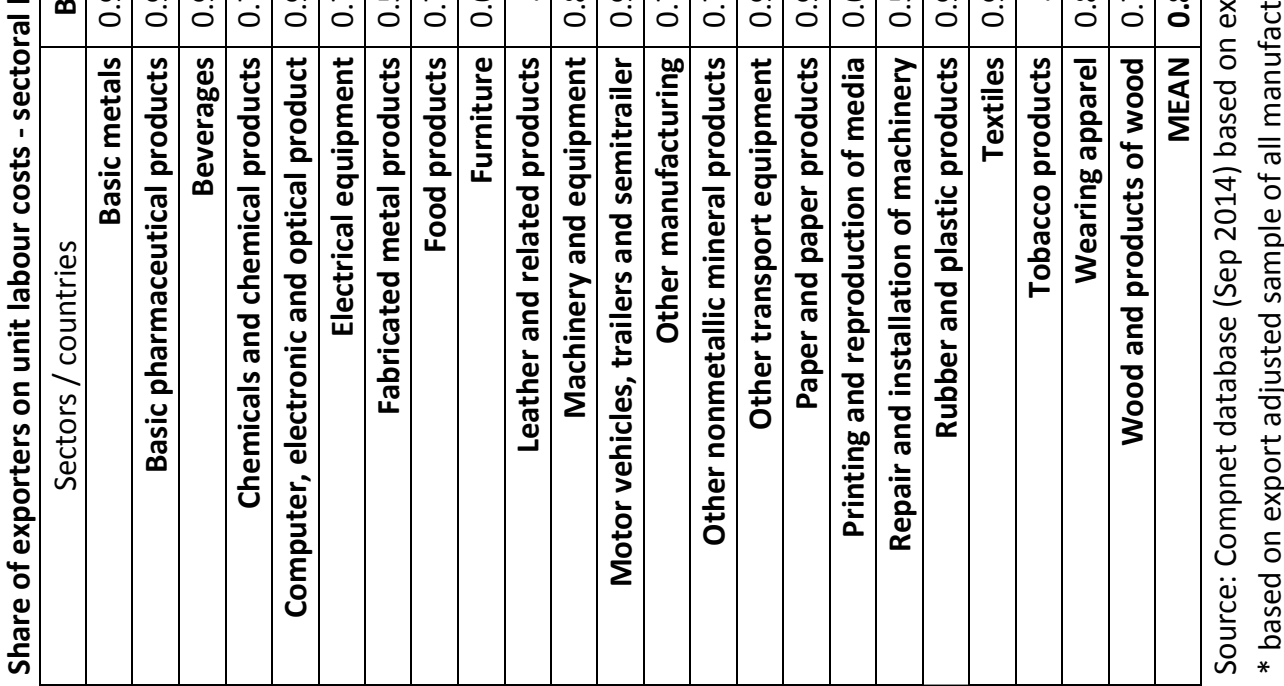




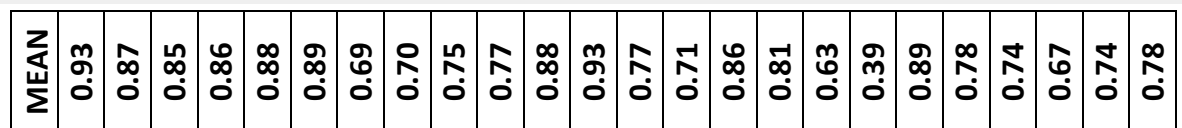

苔 य

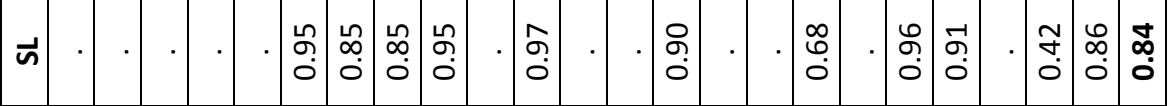

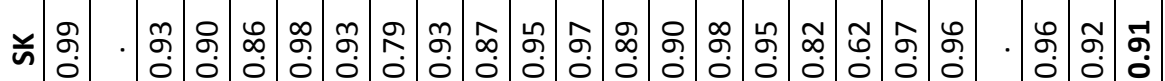
o

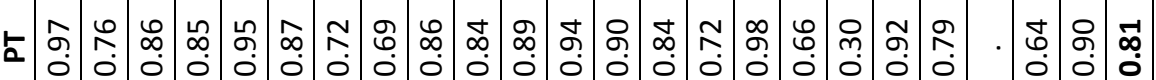

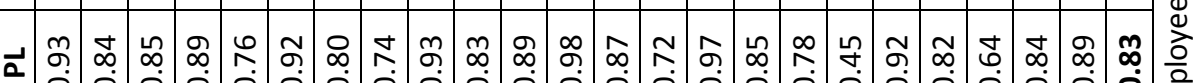

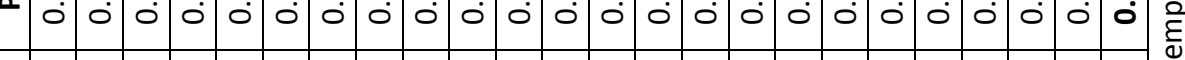

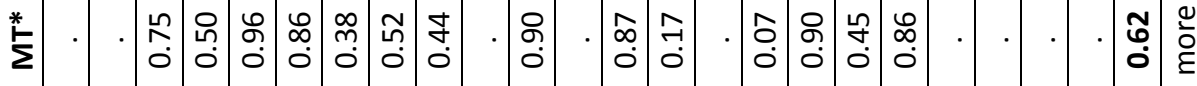

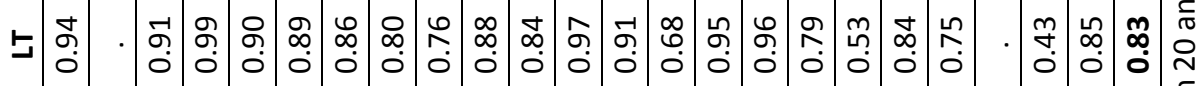

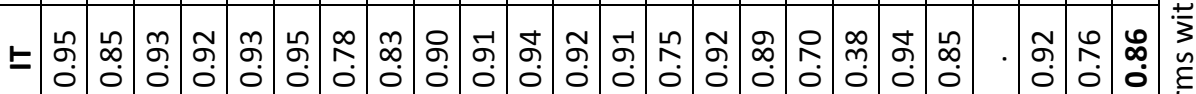
고

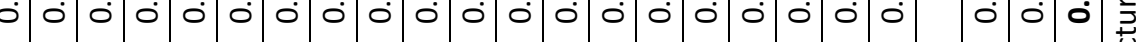

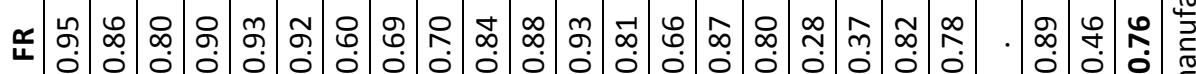

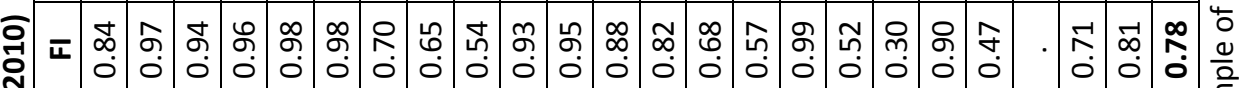

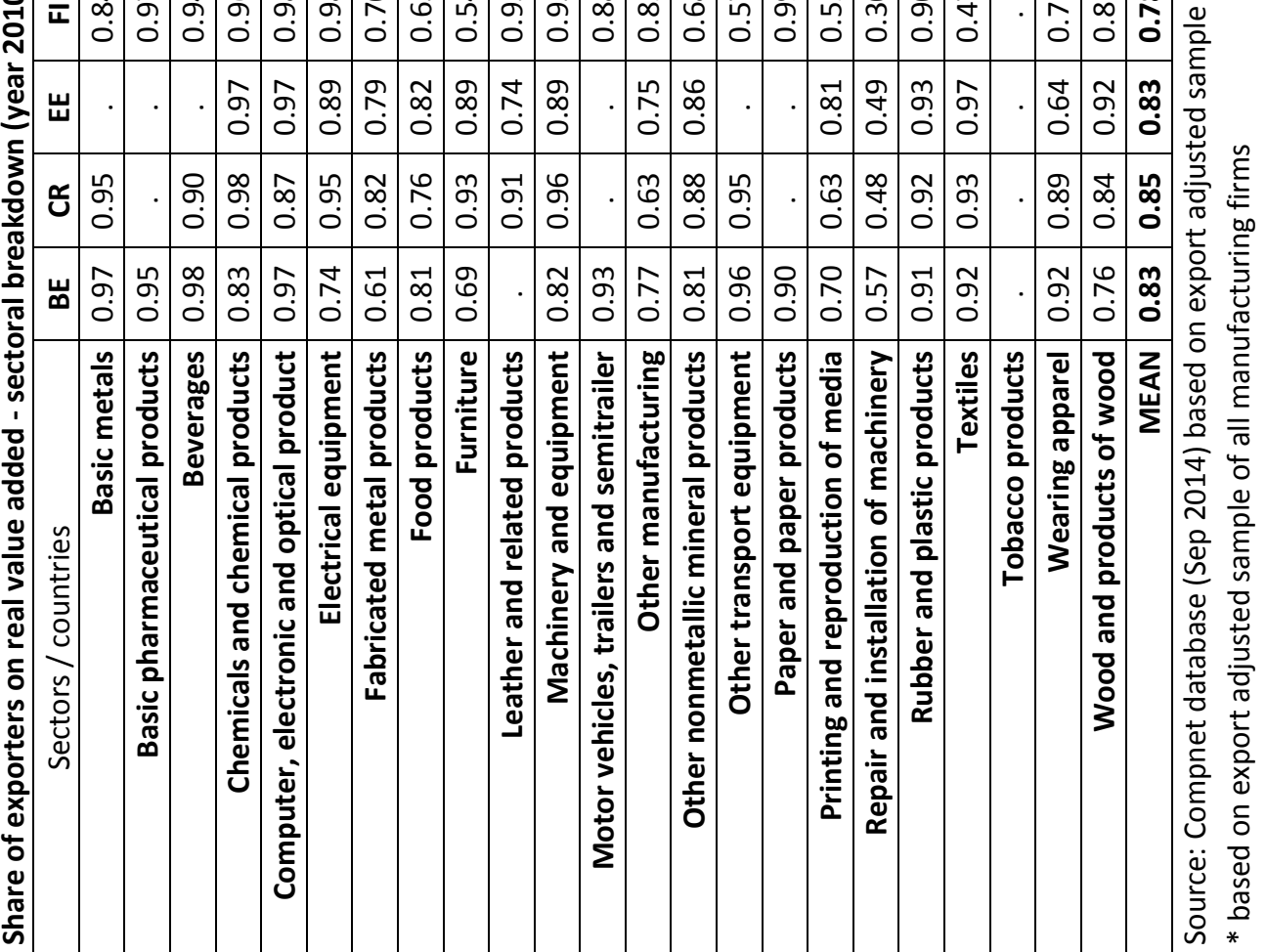




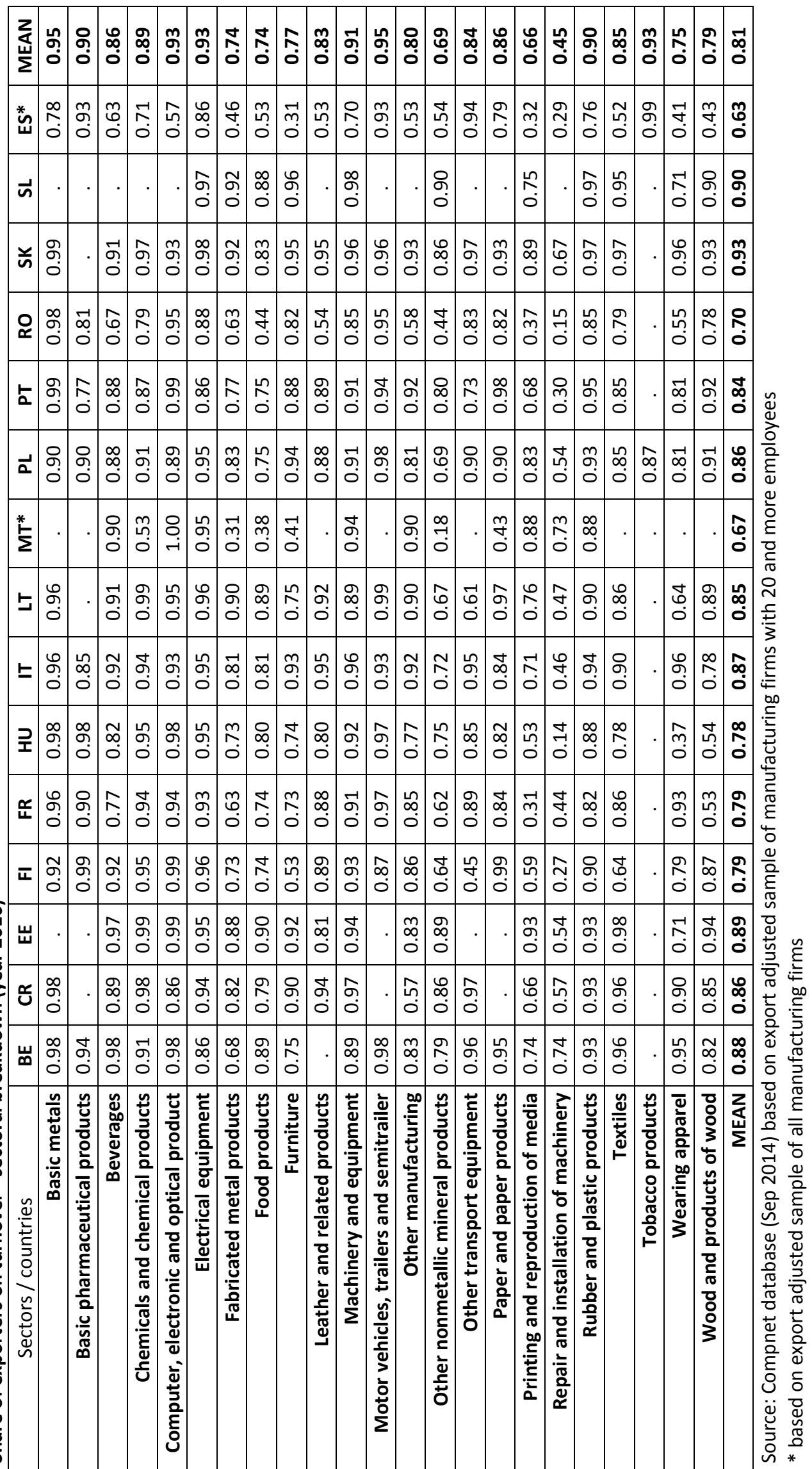




\section{Appendix C. EXPORt Premia}

Figure C.1 - Export premia in TFP (2004-2012)

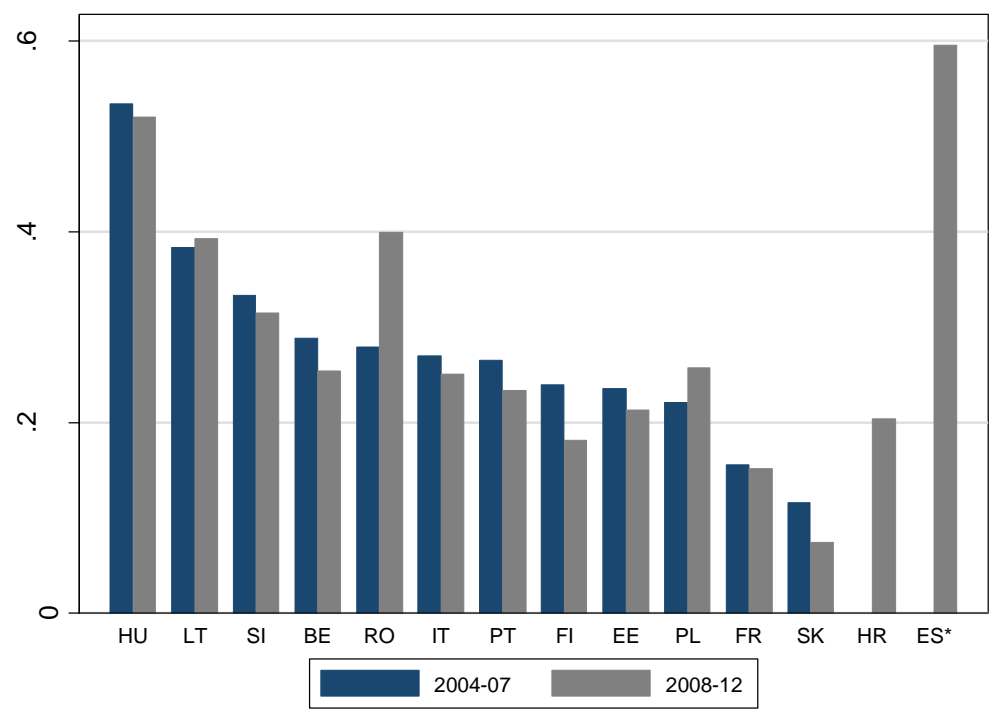

Note: TFP is calculated using the methodology of Wooldridge (2009) (please refer to Lopez-Garcia et al., 2015, for the TFP calculation methodology). Please see also notes of Figure 5.1 .

Figure C.2 - Export premia in wages (2004-2012)

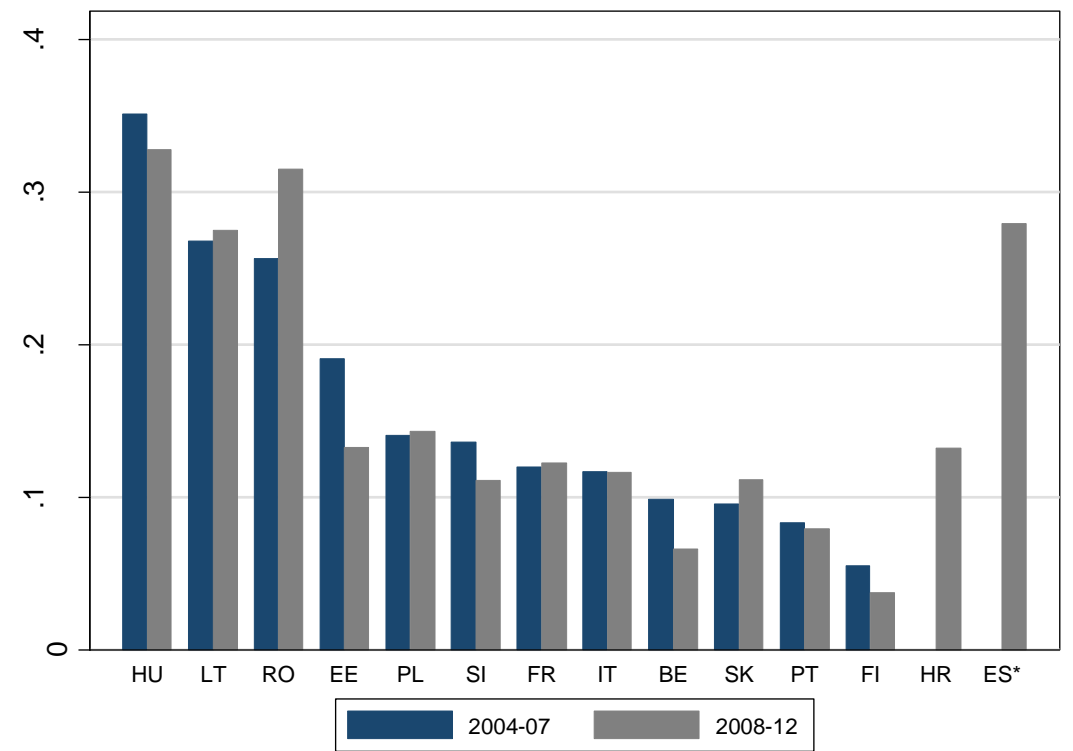

Note: Wages are calculated as real total wage bill per employee. Please see also notes of Figure 5.1. 
Figure C.3 - Export premia in employment (2004-2012)

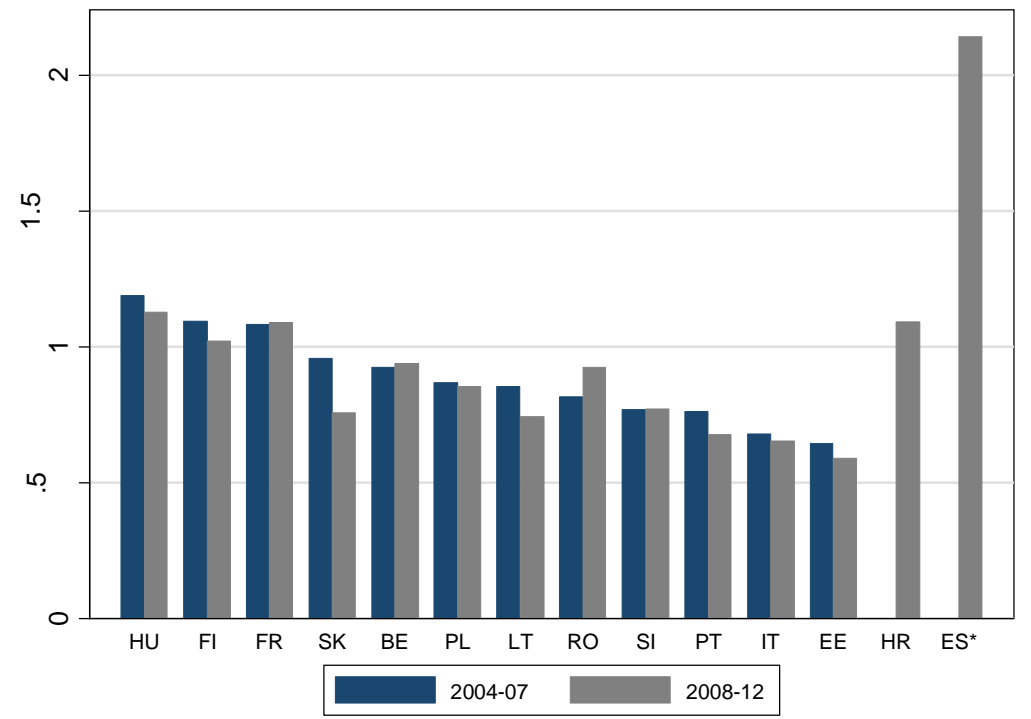

Note: Employment is average yearly number of employees calculated in full-time equivalent. Please see also notes of Figure 5.1 .

Figure C.4 - Export premia in TFP over export status (2004-2012)
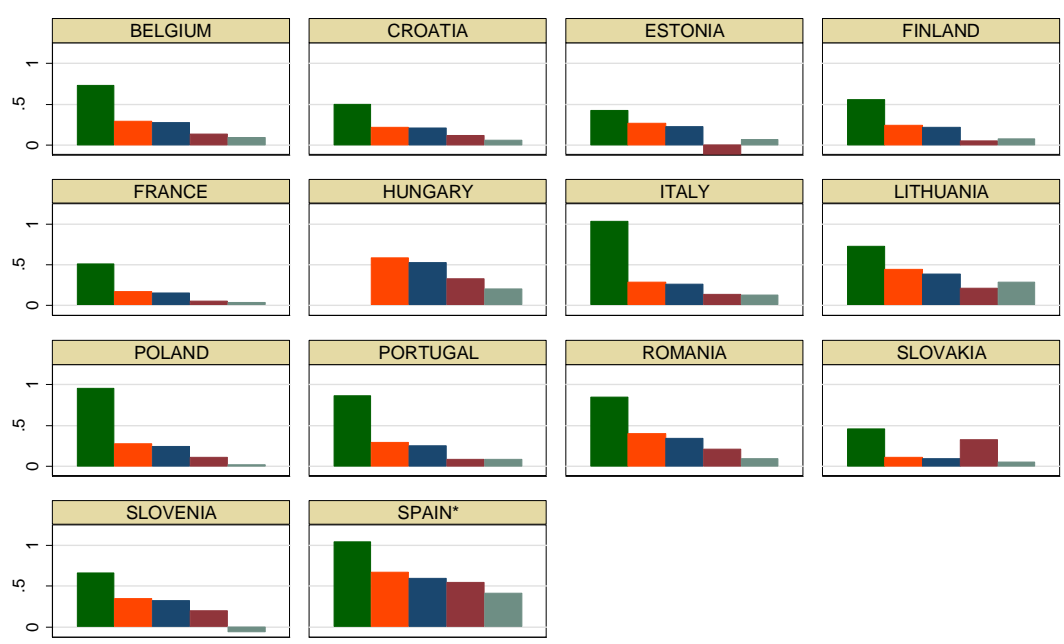

\begin{tabular}{|l|l|}
\hline Top 10 exporters & Permanent exporters \\
New & Exiters \\
\hline
\end{tabular}

Note: Please see also notes on Figure 5.1 and Figure 5.2. 
Figure C.5 - Export premia in labor productivity at the country-level and over export status (2004-2012)
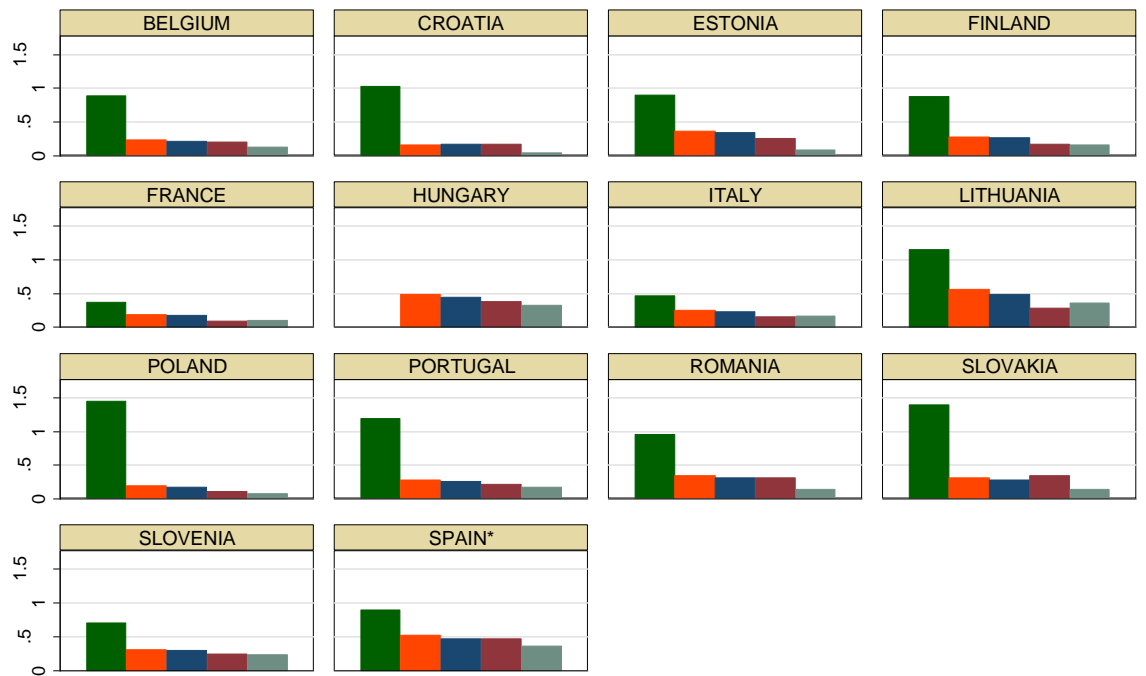

\begin{tabular}{|l|l|}
\hline Top 10 exporters & Permanent exporters \\
New & Exiters \\
\hline
\end{tabular}

Note: Please see also notes on Figure 5.1 and Figure 5.2. 


\section{Appendix D. LIST OF INDICATORS INCLUDED IN THE TRADE MODULE}

\section{General indicators}

\begin{tabular}{|c|c|c|c|}
\hline Indicator & Definition & Statistics & Dimmensions \\
\hline \multicolumn{4}{|l|}{ Productivity indicators } \\
\hline Real Value Added & Value Added Deflated With Sector Specific Deflators & Counts, Mean, Median, IQR, SD, Skewness, Percentiles & All categories of exporters \\
\hline Real Turnover & Turnover Deflated With Sector Specific Deflators & Counts, Mean, Median, IQR, SD, Skewness, Percentiles & All categories of exporters \\
\hline Labour Costs & Nominal Labour Costs & Counts, Mean, Median, IQR, SD, Skewness, Percentiles & All categories of exporters \\
\hline Labour Costs Per Employee & Nominal Labour Costs Divided By The Number Of Employees & Counts, Mean, Median, IQR, SD, Skewness, Percentiles & All categories of exporters \\
\hline Real Capital & Capital Deflated With Gdp Deflator & Counts, Mean, Median, IQR, SD, Skewness, Percentiles & All categories of exporters \\
\hline Capital Intensity & Real Capital Divided By The Number Of Employees & Counts, Mean, Median, IQR, SD, Skewness, Percentiles & All categories of exporters \\
\hline Labour Productivity & Real Value Added Divided By The Number Of Employees & Counts, Mean, Median, IQR, SD, Skewness, Percentiles & All categories of exporters \\
\hline Labour Productivity Revenue & Real Turnover Divided By The Number Of Employees & Counts, Mean, Median, IQR, SD, Skewness, Percentiles & All categories of exporters \\
\hline Unit Labour Costs & Labour Costs Divide By Real Value Added & Counts, Mean, Median, IQR, SD, Skewness, Percentiles & All categories of exporters \\
\hline Capital Productivity & Real Value Added Divided By The Value Of Capital & Counts, Mean, Median, IQR, SD, Skewness, Percentiles & All categories of exporters \\
\hline $\operatorname{Tfp}$ & Total Factor Productivity. For Details, See Section 3.2 & Counts, Mean, Median, IQR, SD, Skewness, Percentiles & All categories of exporters \\
\hline Marginal Product Capital & For Details, See Section 3.2 & Counts, Mean, Median, IQR, SD, Skewness, Percentiles & All categories of exporters \\
\hline Marginal Product Labour & For Details, See Section 3.2 & Counts, Mean, Median, IQR, SD, Skewness, Percentiles & All categories of exporters \\
\hline Wageshare & Labour Costs Divided By Nominal Value Added & Counts, Mean, Median, IQR, SD, Skewness, Percentiles & All categories of exporters \\
\hline \multicolumn{4}{|l|}{ Financial indicators } \\
\hline Investment Ratio & (Growth Rate Of Capital + Depreciation) Divided By Capital & Counts, Mean, Median, IQR, SD, Skewness, Percentiles & All categories of exporters \\
\hline Leverage & Debt Divided By Total Assets & Counts, Mean, Median, IQR, SD, Skewness, Percentiles & All categories of exporters \\
\hline Return On Assets & Operating Profit-Loss Divided By Total Assets & Counts, Mean, Median, IQR, SD, Skewness, Percentiles & All categories of exporters \\
\hline Cash Holding & Cash Divided By Total Assets & Counts, Mean, Median, IQR, SD, Skewness, Percentiles & All categories of exporters \\
\hline Financial Gap & Approx Investment - Cash Flow & Counts, Mean, Median, IQR, SD, Skewness, Percentiles & All categories of exporters \\
\hline Collateral & Capital Divided By Total Assets & Counts, Mean, Median, IQR, SD, Skewness, Percentiles & All categories of exporters \\
\hline Equity_Debt & Equity Divided By Debt & Counts, Mean, Median, IQR, SD, Skewness, Percentiles & All categories of exporters \\
\hline Cash_Flow_Ta & Cash Flow Divided By Total Assets & Counts, Mean, Median, SD, IQR & All categories of exporters \\
\hline Implicit Rate & Interest Paid Divided By Total Debt & Counts, Mean, Median, SD, IQR & All categories of exporters \\
\hline Trade Credit & Creditors Divided By Total Assets & Counts, Mean, Median, SD, IQR & All categories of exporters \\
\hline Trade Debit & Debtors Divided By Total Assets & Counts, Mean, Median, SD, IQR & All categories of exporters \\
\hline Inv_Turnover & Investment Divided By Turnover & Counts, Mean, Median, SD, IQR & All categories of exporters \\
\hline Capital Depreciation & Depreciation Divided By Total Assets & Counts, Mean, Median, SD, IQR & All categories of exporters \\
\hline Debt Burden & Interest Paird Divided By Operating Profit-Loss & Counts, Mean, Median, SD, IQR & All categories of exporters \\
\hline Equity_Ratio & Equity Divided By Total Assets & Counts, Mean, Median, SD, IQR & All categories of exporters \\
\hline Dividends & Dividends & Counts, Mean, Median, SD, IQR & All categories of exporters \\
\hline Profit Margin & $\begin{array}{l}\text { Operating Profit-Loss Divided By Turnover } \\
\text { Index Of Financial Position Of Firm, Computed According To Section }\end{array}$ & Counts, Mean, Median, SD, IQR & All categories of exporters \\
\hline Credit Constraint Indicator & 3.2 & Counts, Mean, Median, IQR, SD, Skewness, Percentiles & All categories of exporters \\
\hline
\end{tabular}

\section{Export performance}

\begin{tabular}{|c|c|}
\hline Statistic & Dimmensions \\
\hline the share of exporting firm & size class and deciles of I, rva, tfp and Iprod \\
\hline the share of non-exporting firms & size class and deciles of I, rva, tfp and Iprod \\
\hline the share of continous exporting firms & size class and deciles of I, rva, tfp and Iprod \\
\hline the share of new exporting firms & size class and deciles of I, rva, tfp and Iprod \\
\hline the share of new non-exporting firms & size class and deciles of I, rva, tfp and Iprod \\
\hline the share of export switching firms & size class and deciles of I, rva, tfp and Iprod \\
\hline the share of continous non-exporting firms & size class and deciles of I, rva, tfp and Iprod \\
\hline the share of importing firms & size class and deciles of I, rva, tfp and Iprod \\
\hline the share of non-importing firms & size class and deciles of I, rva, tfp and Iprod \\
\hline the share of importing-exporting firms & size class and deciles of I, rva, tfp and Iprod \\
\hline mean export value & size class and deciles of I, rva, tfp and Iprod \\
\hline mean exports in value added over turnover & size class and deciles of I, rva, tfp and Iprod \\
\hline mean export value over turnover & size class and deciles of I, rva, tfp and Iprod \\
\hline $\begin{array}{l}\text { median of export value (either adjusted or unadjusted, } \\
\text { it depends from the name of the .dta file in which it is contained) }\end{array}$ & size class and deciles of I, rva, tfp and Iprod \\
\hline median of exports in value added over turnover & size class and deciles of I, rva, tfp and Iprod \\
\hline median of export value over turnover & size class and deciles of I, rva, tfp and Iprod \\
\hline share of exports in turnover & size class and deciles of I, rva, tfp and Iprod \\
\hline
\end{tabular}




\section{Additional trade statistics}

\begin{tabular}{|c|c|c|}
\hline Variable & Statistic & Categories \\
\hline Inexp & Correlations with & I, InIprod, Inmarkup, Intfp, Inulc \\
\hline Inexp_ratio & Correlations with & I, Inlprod, Inmarkup, Intfp, Inulc \\
\hline Inex_vad & Correlations with & I, Inlprod, Inmarkup, Intfp, Inulc \\
\hline export value added & Mean & $\begin{array}{l}\text { Top } 10 \text { firms in terms of labour, Top } 10 \text { firms in terms of exports, Top } 5 \text { firms in terms of labour, } \\
\text { Top } 5 \text { firms in terms of exports, Top } 60 \% \text { firms in terms of exports }\end{array}$ \\
\hline export value & Mean & $\begin{array}{l}\text { Top } 10 \text { firms in terms of labour, Top } 10 \text { firms in terms of exports, Top } 5 \text { firms in terms of labour, } \\
\text { Top } 5 \text { firms in terms of exports, Top } 60 \% \text { firms in terms of exports }\end{array}$ \\
\hline labour & Mean & $\begin{array}{l}\text { Top } 10 \text { firms in terms of labour, Top } 10 \text { firms in terms of exports, Top } 5 \text { firms in terms of labour, } \\
\text { Top } 5 \text { firms in terms of exports, Top } 60 \% \text { firms in terms of exports }\end{array}$ \\
\hline Iprod & mean, median and share out of total & $\begin{array}{l}\text { Firms with exp_ratio }<1 \% \text {, Firms with exp_ratio between } 10 \text { and } 50 \% \text {, Firms with exp_ratio between } 1 \text { and } 5 \% \text {, } \\
\text { Firms with exp_ratio above } 50 \% \text {, Firms with exp_ratio between } 5 \text { and } 10 \%\end{array}$ \\
\hline markups & mean, median and share out of total & $\begin{array}{l}\text { Firms with exp_ratio }<1 \% \text {, Firms with exp_ratio between } 10 \text { and } 50 \% \text {, Firms with exp_ratio between } 1 \text { and } 5 \% \text {, } \\
\text { Firms with exp_ratio above } 50 \% \text {, Firms with exp_ratio between } 5 \text { and } 10 \%\end{array}$ \\
\hline rva & mean, median and share out of total & $\begin{array}{l}\text { Firms with exp_ratio }<1 \% \text {, Firms with exp_ratio between } 10 \text { and } 50 \% \text {, Firms with exp_ratio between } 1 \text { and } 5 \% \text {, } \\
\text { Firms with exp_ratio above } 50 \% \text {, Firms with exp_ratio between } 5 \text { and } 10 \%\end{array}$ \\
\hline tfp & mean, median and share out of total & $\begin{array}{l}\text { Firms with exp_ratio }<1 \% \text {, Firms with exp_ratio between } 10 \text { and } 50 \% \text {, Firms with exp_ratio between } 1 \text { and } 5 \% \text {, } \\
\text { Firms with exp_ratio above } 50 \% \text {, Firms with exp_ratio between } 5 \text { and } 10 \%\end{array}$ \\
\hline ulc & mean, median and share out of total & $\begin{array}{l}\text { Firms with exp_ratio }<1 \% \text {, Firms with exp_ratio between } 10 \text { and } 50 \% \text {, Firms with exp_ratio between } 1 \text { and } 5 \% \text {, } \\
\text { Firms with exp_ratio above } 50 \% \text {, Firms with exp_ratio between } 5 \text { and } 10 \%\end{array}$ \\
\hline
\end{tabular}

